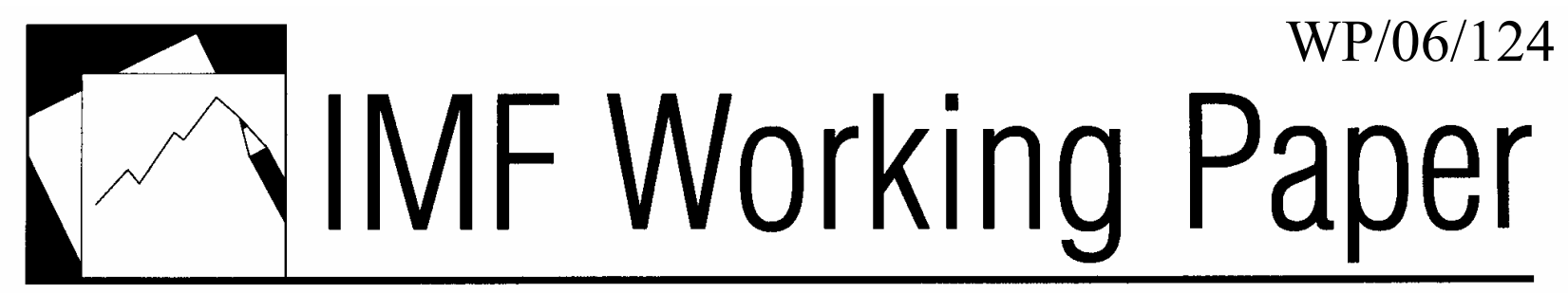

\title{
Indirect Taxes on International Aviation
}

Michael Keen and Jon Strand 



\title{
IMF Working Paper
}

Fiscal Affairs Department

\section{Indirect Taxes on International Aviation}

\section{Prepared by Michael Keen and Jon Strand ${ }^{1}$}

Authorized for distribution by Fiscal Affairs Department

May 2006

\begin{abstract}
This Working Paper should not be reported as representing the views of the IMF. The views expressed in this Working Paper are those of the author(s) and do not necessarily represent those of the IMF or IMF policy. Working Papers describe research in progress by the author(s) and are published to elicit comments and to further debate.

This paper examines the case for internationally coordinated indirect taxes on aviation (as a source of general revenue - not (necessarily) as a source of development finance). The case for such taxes is strong: the tax burden on international aviation is currently limited, yet it contributes significantly to border-crossing environmental damage. A tax on aviation fuel would address the key border-crossing externalities most directly; a ticket tax could raise more revenue; departure taxes face the least legal obstacles. Optimal policy requires deploying both fuel and ticket taxes. A fuel tax of 20 U.S. cents per gallon (10 percent, at today's fuel prices, corresponding to assessed environmental damage), or alternatively ticket taxes of 2.5 percent, would raise about US $\$ 10$ billion if imposed worldwide, and US\$3 billion if applied only in Europe.
\end{abstract}

JEL Classification Numbers: L93; H23; H21

Keywords: Indirect taxation, aviation taxes, tax coordination

Author(s) E-Mail Address:Mkeen@imf.org; Jstrand@imf.org

\footnotetext{
${ }^{1}$ We are grateful to Daniel Boeshertz, to Brian Pearce and colleagues at IATA, for useful information and comments on previous versions of this paper, and to David Pearce, who died tragically in September 2005, for his encouragement and insights into the environmental externalities of aviation. Views and errors are ours alone, and should not be attributed to the International Monetary Fund.
} 


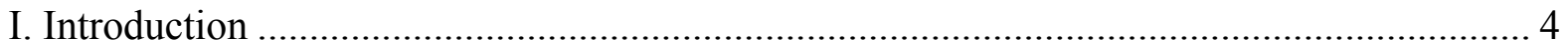

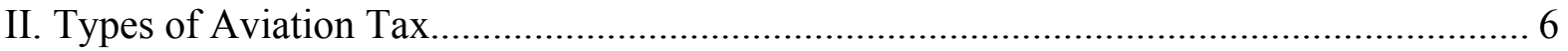

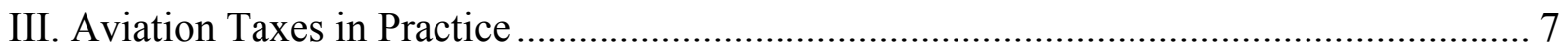

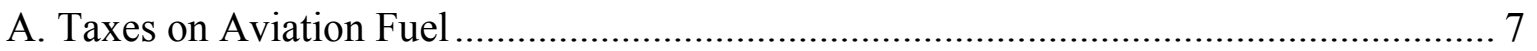

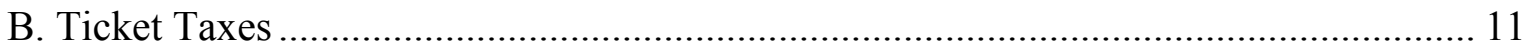

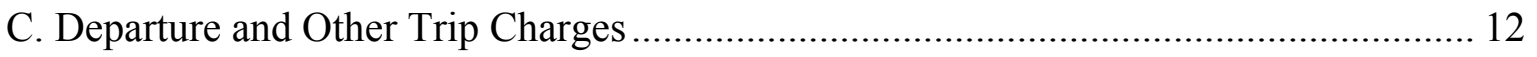

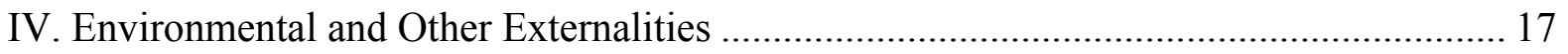

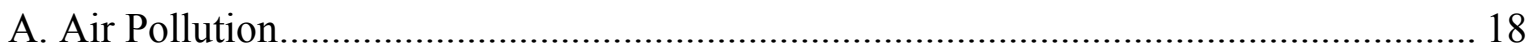

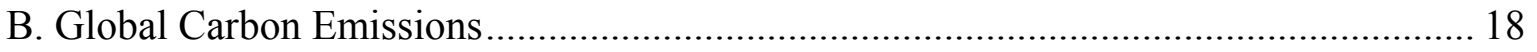

C. Other Emissions Affecting Global Warming ............................................................... 19

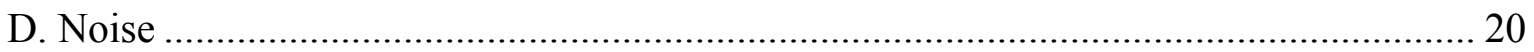

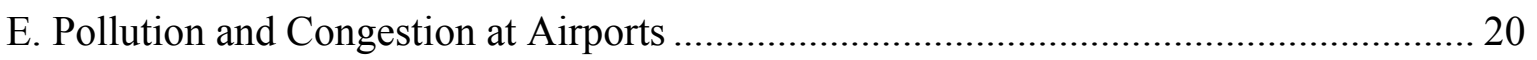

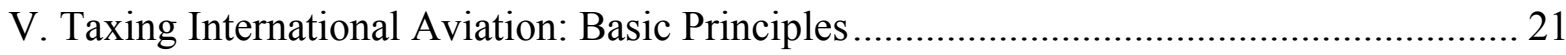

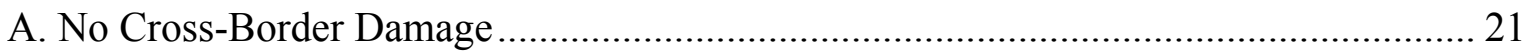

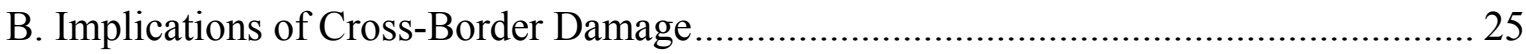

C. Treatment of Business and Economy Travel ............................................................. 27

VI. The Implications of Non-Environmental Distortions in International Aviation .............. 29

A. International Tax Competition ............................................................................. 29

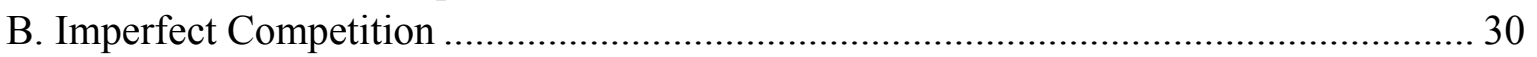

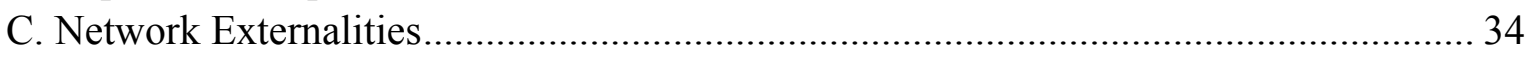

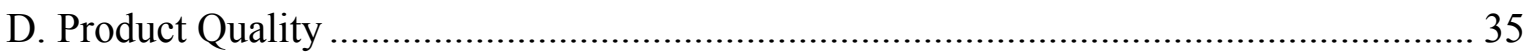

E. Distortions in Competing Modes of Transport......................................................... 36

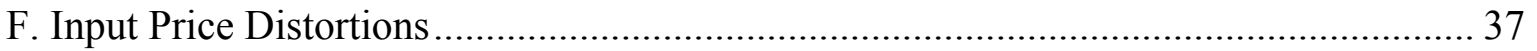

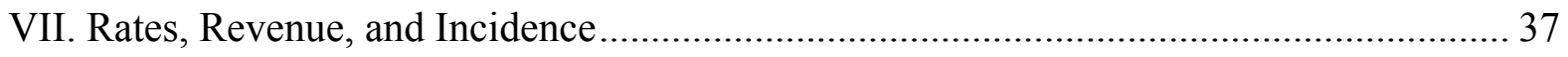

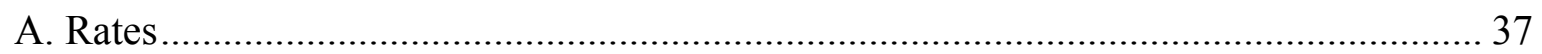

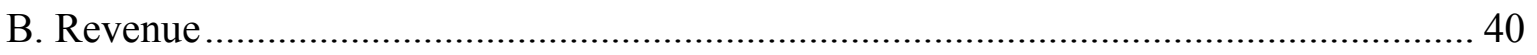

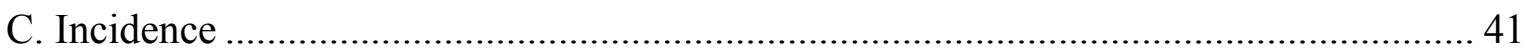

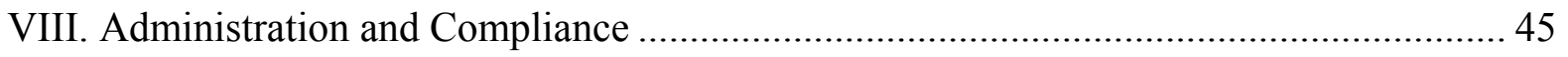

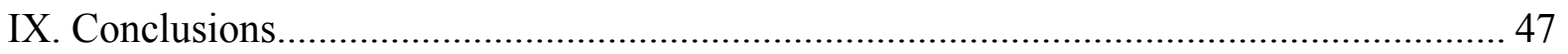

Tables

1. Tax Rates on Domestic Aviation Fuel .................................................................................

2. Domestic Ad Valorem Ticket Taxes, Selected High-Income

Economies, April 2005 ............................................................................................13

3. Ad Valorem Aviation Taxes, Selected Emerging Market and

Developing Economies, April 2005......................................................................14

4. Airport and Departure/Arrival Taxes and Charges, High-Income Economies.....................15

5. Airport and Departure/Arrival Taxes and Charges, Emerging and

Developing Economies 


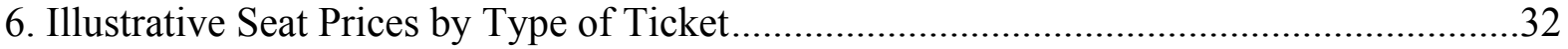

7. Estimated Average Aviation Fuel Tax Necessary to Cover Main Externality Costs (Noise and Air Pollution).....

8. Overall Shares of Aviation Traffic by Travel Class, for Numbers of

Passengers, Distance Traveled, and Airline Revenue.

9. Shares of Total Numbers of Air Passengers by Class, for Traffic

Originating in Different Major Regions

\section{Boxes}

1. The European Debate on Aviation Taxes . .4

2. Other Possible Types of Aviation Tax.

3. Optimal Aviation Tax Rates for Alternative Parameter Values

References 


\section{INTRODUCTION}

There has recently been much discussion of the potential use of global taxes - taxes adopted, that is, by some set of countries on a coordinated basis - as a source of additional finance for development: see in particular Landau and others (2004), Quadripartite Report (2004), and Atkinson (2005). Prominent among the candidate taxes for such a role is some form of indirect tax on international aviation. Such aviation taxes, and voluntary levies of similar nature, have been the subject of lively debate within the European Union, as described in Box 1. And policy initiatives in this area have recently emerged. As of March 2006, France and Chile have decided to proceed with taxes on international flight departures, earmarked for development financing, from 2006. ${ }^{2}$ The United Kingdom and Norway have in addition decided that some fraction of existing (aviation and environmental) taxes will now be earmarked in this way. In addition, about 10 countries (including Brazil) have agreed to adopt the initiative at least in principle.

\section{Box 1. The European Debate on Aviation Taxes}

On June 7, 2005, the Economic and Financial Affairs Council of the European Union (ECOFIN) discussed the issue of a possible contribution to development finance, based on airline tickets, which could be voluntary at two levels: first, each country could decide whether to implement the scheme or not; second, air travelers would themselves choose whether or not to pay the contribution (it being left open whether this would be on an opt-in or opt-out basis). Subsequently, in response to a request from ECOFIN for a closer analysis, the European Commission (2005a) concluded that schemes that are compulsory at the national level are politically infeasible in the EU at the current time, given resistance from several member states (fearing damage to their tourism sectors or airline industries). The document also stresses that schemes that are voluntary at the individual level might run into several problems: they might be excessively burdensome for airlines (requiring significant changes in their accounting and ticketing systems), raise little revenue, and might not be regarded as contributing to countries' official aid.

The Commission's main suggestion is instead for some EU countries to implement a compulsory levy, in the form - because of legal constraints, discussed in the text below — of a departure tax on all domestic and international flights. This would likely be differentiated between economy, business, and first-class passengers, and also possibly between EU and non-EU flights (as is currently the case for the United Kingdom).

\footnotetext{
${ }^{2}$ The French tax, to be imposed from July 2006, will be highly differentiated. In economy class the tax will have the following maximum rates: 1 euro per departure to destinations within Europe, 4 euros to other destinations. For business and first-class travelers, the rates will be 10 and 40 euros, respectively. The Chilean tax is a US\$2 departure tax on all international departures, imposed from the start of 2006.
} 
The purpose of this paper is to develop the public economics of indirect taxes on aviation, ${ }^{3}$ which, before the recent debate, have been little discussed in the public finance literature. The analysis here will leave aside — at least for the most part — the distinct set of issues that arise from the prospective use of the proceeds to finance development rather than simply to augment national tax revenues. ${ }^{4}$ Thus the intention here is not to recommend or dismiss such a tax as a source of development finance, nor is it to reject other candidates. The main purpose is simply to identify, analyze, and assess the merits of various forms of aviation taxes as tax policy measures in their own right.

The central arguments in favor of enhanced taxation of aviation, especially international aviation, are easily stated. Such taxes are currently low (as will be seen below). Yet (as will also be seen) aviation causes significant border-crossing environmental damage, including air pollution (to a large extent on the macro, regional, or global scale) and noise (largely on the micro scale, depending on the location of airports). There may also be a case for a corrective tax on aviation to address greenhouse effects - emissions related to international aviation are, notably, excluded from the recently adopted Kyoto Protocol to the United Nations Framework Convention on Climate Change. Even apart from border-crossing environmental harm, however, taxes on international aviation may be inefficiently low as a result of tax competition, with countries independently choosing to set taxes lower than they would if they behaved in concert, so as to avoid jeopardizing domestic carriers and/or tourist sectors.

These generalities leave many important issues of detail to address. One key issue is which of several possible forms such a tax might take. It might be levied, in particular, on fuel use, as a tax on tickets, and/or on each trip. Should several of these instruments (and other possible charges related to aviation, discussed below) be used, or just one? If only one, which should it be? What would be the appropriate rates of such taxes, and how much revenue would they raise? Could they be administered and complied with at reasonable cost? Do the factors that

\footnotetext{
${ }^{3}$ By an indirect tax on aviation is meant here whose base is associated in some way with the extent of aviation activity. Airlines are subject to corporate tax on their earnings by standard rules of international taxation: typically, under reciprocal arrangements they are taxed only in their country of residence. Direct taxation of aviation is not considered in what follows, and references to "aviation taxes" and the like refer only to indirect taxes.

${ }^{4}$ Thus the paper does not address, in particular, the key question of additionality: the extent to which the use of the proceeds from such a tax to support development would be offset by reductions in other forms of support. On this, see World Bank (2005), Boadway and Keen (2005), and Zee (2005). Broadly speaking, viewing foreign assistance as a Samuelson public good to those who finance it, the prediction is that there will be additionality from a coordinated tax reform amongst them only insofar as this increases the overall efficiency of their tax systems, with its extent then depending on the extent to which the associated increase in real income generates an increase in giving.
} 
have kept such taxes low in the past mean that it is unlikely to prove possible to raise them in the future? Not least: if taxes on international aviation are clearly too low, why have they not been raised before?

The plan of the paper is as follows. Section II takes a first look at the various forms of aviation taxes to be considered, and Section III then outlines key features of current practice. Section IV sets out the main border-crossing externalities arising from international aviation. Section V develops basic theoretical principles for aviation taxes, which are then extended in Section VI in light of other potential distortions in the aviation market. Section VII considers the appropriate rates of aviation taxes, the revenue they would yield, and their likely incidence. Section VIII considers practical issues of administration and compliance. Section IX concludes.

\section{Types Of AViation TaX}

There are several possible types of indirect tax on aviation. The analysis in this paper focuses on three:

- An excise tax - meaning one that (unlike, in particular, the value-added tax (VAT)) is not creditable or refundable to business users - on aviation fuel, which, for brevity, is assumed throughout the analysis to be levied in specific form (that is, as a fixed monetary amount per gallon). ${ }^{5}$

- $\quad$ A ticket tax, by which will be meant an ad valorem excise on sales of passenger tickets and cargo waybills. Note that a VAT on tickets is not a ticket tax in this sense, since it would in principle be creditable for business users.

- A trip tax, meaning some charge that is levied on passengers as a fixed amount per trip, at a common rate for all trips within some wide class. The familiar departure tax is the leading example.

There are obvious and important differences between these instruments. One critical difference is that aviation fuel is an intermediate input (as is business cargo and, perhaps more arguably, business travel). Under conditions that are strong but commonly taken as an appropriate basis for policy formation, the Diamond and Mirrlees (1971a, 1971b) theorem on production efficiency implies that - in the absence of externalities - such items should not be taxed. Thus the fundamental rationale for taxing aviation fuel and business travel and freight

\footnotetext{
${ }^{5}$ Specific taxation is the norm for fuel excises. This reflects a variety of considerations, including the relative constancy of revenues that it implies, given relatively inelastic demand, in the face of varying producer prices.
} 
is the environmental damage referred to above, and explored more below. ${ }^{6}$ Passenger travel, in contrast, is a final consumption item and so is potentially a proper target for final commodity taxation.

But there are also important similarities between these types of tax: indeed, in some cases they are economically equivalent. Under perfect competition for a homogeneous product of unchanging characteristics, for instance, ad valorem and specific taxes have precisely the same effects; any outcome that can be achieved under one can also be achieved under the other. Thus a ticket tax would be equivalent to a trip tax levied in the same monetary amount. More important still, if there were no possibility of changing fuel efficiency, and load factors were similarly fixed, then a tax on aviation fuel would be equivalent to a ticket tax.

The key point is that these taxes operate on somewhat different margins of decision, so that the differences between them arise from the scope for substitution on those various margins. The nature and strength of such responses is thus critical to the comparison among them, a point elaborated below.

There are other types of aviation tax that are or might be implemented, as described in Box 2. It is the three above, however, that have featured most prominently in recent discussions (and are closest to current practice), and on which the analysis here is consequently focused.

\section{Aviation Taxes in Practice}

Aviation is subject to a wide range of fees and charges. Many of these-such as airport landing charges, passenger security charges, and route facility charges imposed by air navigation services - are essentially user fees charged for services, with the proceeds earmarked to aviation-related purposes, rather than taxes whose proceeds are put to general use. The central concern here is with the latter.

\section{A. Taxes on Aviation Fuel}

Domestic aviation fuel is generally subject to VAT. However, since aviation fuel will typically be a business input of an enterprise large enough to be registered for VAT, this component of tax will (in principle at least) be fully credited, and so ultimately will have no economic impact. More relevant to the concerns here, many countries also charge excise taxes on aviation fuel used for domestic flights, sometimes at rates differentiated between propeller planes (which use aviation gasoline) and jets (which use kerosene).

\footnotetext{
${ }^{6}$ Or, in principle, the existence of constraints on the use of other tax instruments,
} 


\section{Box 2. Other Possible Types of Aviation Tax}

An emissions tax would have the advantage relative to an aviation fuel tax of targeting more precisely the proximate cause of pollution damage: it would encourage airlines to reduce emissions for given fuel input, for instance through their engine choice.

A noise tax would be best targeted to noise pollution (and might be encompassed within airport landing charges). Swiss airports currently have such taxes, for example.

A local air pollution tax would tax aircraft emissions specifically at individual airports and would depend on the local marginal pollution damage cost. Relative to other taxes, it would have the potential advantage (together with the noise tax) of shifting some of the air traffic volume away from airports with high marginal damage, to airports with lower damage.

A variant of a departure tax, used by Norway since 1995, is a "green" levy on all national flights for which there is a rail alternative.

A levy on airspace could serve to allocate efficiently airspace resources that, at least in some cases, could become congested (WGBU, 2002).

A wide range of quasi-taxes and charges (in the forms of levies and charges for airport use, landing, and navigation fees) act as aviation taxes to the extent that they are levied at rates differing from the marginal private benefit of services received.

Systematic aviation fuel tax data are hard to come by. Table 1 reports the rates recently applied to domestic aviation fuel in a selection of countries for which data are available. In the United States, domestic aviation fuel is taxed at the state level, with rates varying across them (and with no tax in some). ${ }^{7}$ Table 1 reports both the specific amount (in US\$) and the equivalent ad valorem (that is, the specific tax relative to the price of fuel). The rates are in many cases similar for aviation gasoline and jet fuel, but where they differ, the jet fuel tax (which is the more important in practice) is the lower. Among Organization for Economic Co-operation and Development (OECD) countries, Norway has had a domestic aviation fuel tax since 1999 (currently 0.28 NOK per liter, equivalent to US\$0.16 per gallon). ${ }^{8}$ The Netherlands and Japan have also recently imposed quite high aviation fuel taxes (respectively, 0.20 and 0.24 euro per liter), again only for domestic flights.

\footnotetext{
${ }^{7}$ Some states provide airlines with guarantees as to the maximum amount of fuel tax they will pay.

${ }^{8}$ See ECON (2005) for a further discussion of the Norwegian aviation tax regime and its development.
} 
Table 1. Tax Rates on Domestic Aviation Fuel

(Selected countries, various years)

\begin{tabular}{lcccc}
\hline & $\begin{array}{c}\text { Aviation gasoline } \\
\text { (USD per gallon) }\end{array}$ & $\begin{array}{c}\text { Aviation Gasoline, } \\
\text { (In percent) }\end{array}$ & Jet Fuel (US\$) & $\begin{array}{c}\text { Jet Fuel 7/ } \\
\text { (In percent) }\end{array}$ \\
\hline Australia 5/ & 0.09 & 8 & 0.09 & 8 \\
Bolivia 1/ & 0.21 & 9.3 & 0.21 & 17.4 \\
Brazil 3/ & 1.57 & 40.4 & 0.06 & 4.9 \\
Canada 5/ & 0.06 & 6 & 0.06 & 6 \\
Costa Rica 4/ & 0.96 & 38.7 & 0.58 & 38.4 \\
Ecuador 1/ & 0.36 & 15.8 & 0.16 & 15.4 \\
Indonesia 2/ & 0.02 & 7.7 & 0.16 & 13.2 \\
Japan 5/, 6/ & 1.10 & 96 & 1.10 & 96 \\
Netherlands 5/, 6/ & 0.92 & 81 & 0.92 & 81 \\
Nicaragua 4/ & 0.91 & 21.7 & 0.01 & 0.7 \\
Norway 5/ & 0.16 & 14 & 0.16 & 14 \\
Paraguay 1/ & 0.32 & 9.2 & 0.01 & 1.1 \\
Peru 4/ & 0.58 & 15.9 & 0.25 & 16.1 \\
Philippines 5/ & & & 0.30 & 27.5 \\
Taiwan 1/ & 0.89 & 59.4 & 0.06 & 3.3 \\
Uruguay 5/ & 0.09 & 5.0 & 0.09 & 5.0 \\
United States 5/ & 0.19 & 0.22 & 21.0 \\
Venezuela 2/ & 0.05 & 0.04 & 5.0 \\
\hline
\end{tabular}

Source: Energy Détente, various issues, and personal communication.

$1 /=2000$

$2 /=2001$

$3 /=2002$

$4 /=2003$

$5 /=2004$

6/ only for domestic flights.

7/ percent of average fuel prices in the respective year, in most cases around US\$1 per gallon for 2000-03, US\$1.50 per gallon for 2004 . 
There is typically no tax, however, on aviation fuel used on international flights. Under the VAT, items related to international transport are generally zero-rated (meaning that no tax is charged on sales, and any tax paid on inputs is refunded), reflecting the typical objective of excluding exports from the VAT in order to make it a destination-based tax on domestic consumption. The absence of an excise on fuel used in international aviation, however, stands in sharp contrast to the high excise rates that are often charged on other fuels (which are not rebated when used in the production of exports).

The exemption of international aviation fuel is to a large degree enshrined in the legal framework of international aviation:

- $\quad$ Article 24 of the 1944 Convention on International Civil Aviation (the Chicago Convention), ${ }^{9}$ which provides the overarching legal framework for international aviation, requires that: "Fuel, lubricating oils [and other items] on board an aircraft of a contracting State, on arrival in the territory of another contracting State and retained on board on leaving the territory of that State, shall be exempt from customs duty, inspection fees or similar national or local duties and charges." 10 The Chicago Convention does not, however, prevent countries from taxing fuel purchased for international flights in their own jurisdictions; nor does it prevent them from taxing aviation fuel used on purely domestic flights. But it does mean that they cannot undo any incentive for carriers to fuel flights from that country by tanking in lower tax jurisdictions.

- Bilateral air service agreements also typically include a mutual agreement not to tax aviation fuel. In the EU, however, there is now no direct legal impediment to the taxation, by mutual agreement, of aviation fuels used on flights between EU member states. ${ }^{11}$

The rationale for these legal undertakings is by no means clear. They may reflect an attitude, common in the early days of the industry, that international air travel conveyed beneficial externalities and ought to be positively encouraged. What is clear, however, is that these

\footnotetext{
${ }^{9}$ The Chicago Convention, signed in 1944 and ratified in 1947, provides the legal framework for international civil aviation activity and established the International Civil Aviation Organization (ICAO). It now has 188 signatories, including those most prominent in civil aviation.

${ }^{10}$ The interpretation of this article is clarified in a 1999 resolution of the International Civil Aviation Organization, spelling out for instance that it is intended to apply to local as well as national taxes, and to nonscheduled as well as scheduled flights (ICAO, 2000).

${ }^{11}$ This reflects the terms of Directive 2003/96 on energy taxation. On this point, see European Commission (2005a).
} 
agreements place significant obstacles in the way of taxing international aviation fuel. ${ }^{12}$ Given the diversity of countries' views on the desirability of taxing aviation fuel and the potential for opening up a still wider set of issues, renegotiating the Chicago Convention appears currently out of the question. Bilateral air services could of course be renegotiated bilaterally, and to that extent are perhaps a lesser obstacle, although their sheer number (there are several thousand) would likely make this a very painstaking process.

It is also unclear whether these agreements currently act as binding constraints on national policies towards the taxation of international aviation fuel. Even in the absence of legal restrictions, international tax competition might lead to inefficiently low levels of fuel taxation. To the extent that planes are technically able, at some cost, to carry into a country enough fuel for journeys out of it (a Boeing 747, for example, can in principle travel from New York to London and back on a single tank of fuel) - and to the extent that safety rules allow them to do so- high fuel taxes in any country could be avoided by tanking in lower tax jurisdictions. Even if countries were unrestricted in their ability to tax all fuel used on outbound international flights, each acting in isolation might well be inclined to set a low or zero rate in order to maintain its attractiveness relative to other destinations, or as hubs in airlines' operation patterns, even though collectively all would benefit from a mutual increase in tax rates. Thus action to weaken the legal restrictions would be necessary for an increase in tax levels, but it might not be sufficient: collective action in rate-setting would also be required.

\section{B. Ticket Taxes}

Ad valorem taxes — ones, that is, proportional to the price charged - may also be levied on tickets issued to passengers and prices charged for cargo (waybills). These too may take the form of either a VAT or a non-creditable excise, and again treatment commonly varies between domestic and international travel. In this case the role of the VAT is rather different, and potentially more significant, than in the case of aviation fuel. This is because, although the tax will typically be credited when charged on business-related travel, it will be final for purchases by final consumers.

Domestic air travel is quite widely subject to VAT, as shown in the first column of Table 2 for high-income countries and the first column of Table 3 for selected developing and emerging market economies. In the EU, all member states except Denmark, Ireland, and the United Kingdom charge VAT on domestic aviation services, although (except for Germany and the Netherlands) they do so at a rate lower than their standard. Practice also varies quite

\footnotetext{
${ }^{12}$ For further discussion, see for instance Sledsens (1998).
} 
widely across developing and emerging market economies, although the impression from the table is that zero-rating of domestic aviation is rather more common in these countries.

Tables 2 and 3 also show non-creditable ad valorem ticket taxes imposed on domestic aviation. These are quite rare in high-income countries, being charged only by a few that do not levy VAT. The 7.5 percent for the United States is an earmarked security charge, which also comprises a fixed charge of US\$3.20 per segment for domestic air travel (and US\$14.10 per takeoff and landing for international travel). ${ }^{13}$

International travel, on the other hand, is typically zero-rated under the VAT. ${ }^{14}$ This is the case for all high-income countries in Table 2; a few developing and emerging market countries, however - notably in Latin America - do impose VAT on international travel. Ad valorem ticket taxes on international travel are also confined to developing and emerging market countries; where levied, they are generally at lower rates than apply domestically, presumably reflecting international competitiveness concerns. Of the countries for which we have information, only Argentina levies both VAT and an ad valorem ticket tax on international travel. Note also that in the rather few cases in which international ticket taxes are levied, this is typically only for tickets sold in the country. ${ }^{15}$

Within the EU, ad valorem ticket taxes would arguably run counter to rules requiring the VAT to be the only broad-based turnover tax, so that the prospects of such a tax in the EU are remote. There is no reason in principle, however, why VAT should not be charged on international air travel.

\section{Departure and Other Trip Charges}

The third main set of instruments is charges specified as fixed amounts per passenger.

Tables 4 and 5 report charges of this kind for, respectively, samples of high-income and developing/emerging market economies. While the IATA data from which these tables are compiled distinguish between "airport charges" (which usually accrue to the airport authority) and arrival/departure taxes (which usually accrue to government), many countries

\footnotetext{
${ }^{13}$ NBAA (2005). "Domestic" in the United States includes a zone 225 miles north and south of the border.

${ }^{14}$ All EU members except Sweden zero-rate international aviation activity, including flights among members. Sweden has an option to tax intercountry EU flights, as a derogation from $6^{\text {th }}$ VAT Directive.

${ }^{15}$ In Argentina and Costa Rica, which have the most significant such taxes, travel starting abroad is exempt, as are tickets sold outside Argentina to non-Argentines.
} 
Table 2. Domestic Ad Valorem Ticket Taxes, Selected High-Income Economies, April 2005

(In percent)

\begin{tabular}{|c|c|c|}
\hline & Domestic VAT & Domestic Ticket Tax \\
\hline Australia & 10 & 0 \\
\hline Austria & 10 & 0 \\
\hline Belgium & 6 & 0 \\
\hline Canada & 0 & 7 \\
\hline Denmark & 0 & 0 \\
\hline Finland & 8 & 0 \\
\hline France & 5.5 & 0 \\
\hline Germany & 16 & 0 \\
\hline Greece & 8 & 0 \\
\hline Hong Kong & 0 & 0 \\
\hline Ireland & 0 & 0 \\
\hline Israel & 0 & 0 \\
\hline Italy & 10 & 0 \\
\hline Japan & 0 & 5 \\
\hline Netherlands & 6 & 0 \\
\hline New Zealand & 12.5 & 0 \\
\hline Norway & 7 & 0 \\
\hline Singapore & 0 & 0 \\
\hline Spain & 7 & 0 \\
\hline Sweden & 6 & 0 \\
\hline Switzerland & 7 & 0 \\
\hline United Kingdom & 0 & 0 \\
\hline United States of America & 0 & 7.5 \\
\hline
\end{tabular}

Source: IATA (2005a). 
Table 3. Ad Valorem Aviation Taxes, Selected Emerging Market and Developing Economies, April 2005

$$
\text { (In percent) }
$$

\begin{tabular}{|c|c|c|c|c|}
\hline Country & $\begin{array}{l}\text { Domestic } \\
\text { VAT }\end{array}$ & $\begin{array}{c}\text { International } \\
\text { VAT }\end{array}$ & $\begin{array}{l}\text { Domestic } \\
\text { Ticket Tax }\end{array}$ & $\begin{array}{c}\text { International } \\
\text { Ticket Tax }\end{array}$ \\
\hline Argentina & 10.5 & 0 & 14 & 5 \\
\hline Brazil & 0 & 0 & 3 & 0 \\
\hline Chile & 0 & 0 & 0 & 0 \\
\hline China & 0 & 0 & 0 & 0 \\
\hline Colombia & 16 & $8-16$ & 0 & 0 \\
\hline Costa Rica & 0 & 0 & 0 & 5 \\
\hline India & 0 & 0 & 10 & 0 \\
\hline Indonesia & 0 & 0 & 0 & 0 \\
\hline Korea & 10 & 0 & 0 & 0 \\
\hline Malaysia & 0 & 0 & 0 & 0 \\
\hline Mexico & $2.5-10$ & $2.5-4$ & 0 & 0 \\
\hline Nigeria & 0 & 0 & 0 & 0 \\
\hline Pakistan & 0 & 0 & 20 & 1 \\
\hline Peru & 19 & 19 & 0 & 0 \\
\hline Philippines & 0 & 0 & 0 & 0 \\
\hline Poland & 7 & 0 & 0 & 0 \\
\hline Russia & 0 & 0 & 0 & 0 \\
\hline Saudi Arabia & 0 & 0 & 0 & 0 \\
\hline South Africa & 14 & 0 & 0 & 0 \\
\hline Taiwan & 5 & 0 & 0 & 0 \\
\hline Thailand & 10 & 7 & 0 & 0 \\
\hline Turkey & 0 & 0 & 0 & 0 \\
\hline Ukraine & 0 & 0 & 0 & 0 \\
\hline Venezuela & 0 & 0 & 9 & 1 \\
\hline
\end{tabular}

Source: IATA (2005a). 
Table 4. Airport and Departure/Arrival Taxes and Charges, High-Income Economies

(US\$ per traveler, rates as of April 2005, exchange rates as of June 2005)

\begin{tabular}{|c|c|c|c|c|c|c|}
\hline \multirow[b]{2}{*}{ Country } & \multicolumn{2}{|c|}{ Airport Charges } & \multicolumn{2}{|c|}{ Departure Charges } & \multicolumn{2}{|c|}{$\underline{\text { Total Passenger Charges }}$} \\
\hline & Domestic & International & Domestic & International & Domestic & International \\
\hline Australia & $6-22$ & $11-19$ & 30 & 30 & $36-52$ & $41-49$ \\
\hline Austria & 16 & 16 & 0 & $16-17$ & 16 & 32 \\
\hline Belgium & 0 & 0 & 0 & $12-25$ & 0 & $12-25$ \\
\hline Canada & $16-20$ & $22-26$ & 0 & 0 & $16-20$ & $22-26$ \\
\hline Denmark & $8-16$ & 20 & 12 & 12 & $20-26$ & 32 \\
\hline Finland & 3 & 3 & 7 & $6-12$ & 10 & $9-15$ \\
\hline France & 15 & $9-16$ & 0 & 0 & 15 & $9-16$ \\
\hline Germany & $13-22$ & $11-19$ & 0 & 0 & $13-22$ & $11-19$ \\
\hline Greece & 29 & 44 & 0 & 0 & 29 & 44 \\
\hline Hong Kong & 0 & 0 & 0 & 15 & 0 & 15 \\
\hline Ireland & $4-6$ & $4-6$ & 10 & 10 & $14-16$ & $14-16$ \\
\hline Israel & 12 & 12 & 0 & $8-55$ & 12 & $20-67$ \\
\hline Italy & 6 & 6 & $7-11$ & $7-11$ & $13-19$ & $13-19$ \\
\hline Japan & $1-2$ & $11-28$ & 0 & 0 & $1-$ & $11-28$ \\
\hline Netherlands & $40-42$ & $40-42$ & 0 & 0 & $40-42$ & $40-42$ \\
\hline New Zealand & 4 & 11 & 0 & $14-18$ & 4 & $25-29$ \\
\hline Norway & 12 & 17 & 0 & 0 & 12 & 17 \\
\hline Singapore & 0 & 0 & 0 & $10-13$ & 0 & $10-13$ \\
\hline Spain & 1 & 1 & $4-5$ & $5-8$ & $5-6$ & $6-9$ \\
\hline Sweden & $11-18$ & $12-25$ & 0 & 0 & $11-18$ & $12-25$ \\
\hline Switzerland & 0 & 0 & 6-28 1/ & $6-281 /$ & $6-28$ & $6-28$ \\
\hline United Kingdom & $15-27$ & $18-36$ & 11 & $9-732 /$ & $26-38$ & $27-109$ \\
\hline $\begin{array}{l}\text { United States of } \\
\text { America }\end{array}$ & 3 & 3 & 19 & 31 & 22 & 34 \\
\hline
\end{tabular}

Source: IATA (2005a).

1/ Includes a specific noise tax, differentiated by airport.

2/ Rate differentiated by economy-, business- and first-class, and by destination (EU/non-EU). 
Table 5. Airport and Departure/Arrival Taxes and Charges, Emerging and Developing Economies

(US\$ per traveler rates as of April 2005, exchange rates as of June 2005)

\begin{tabular}{|c|c|c|c|c|c|c|}
\hline & \multicolumn{2}{|c|}{ Airport Charges } & \multicolumn{2}{|c|}{ Departure Charges } & \multicolumn{2}{|c|}{ Total Passenger Charges } \\
\hline & Domestic & International & Domestic & International & Domestic & International \\
\hline Argentina & 1 & 12 & 2 & 18 & 1 & 30 \\
\hline Brazil & 0 & 0 & $2-4$ & $12-36$ & $2-4$ & $12-36$ \\
\hline Chile & $3-8$ & 8 & 0 & $20 / 501 /$ & $3-8$ & 8 \\
\hline China & 6 & 11 & 0 & 0 & 6 & 11 \\
\hline Colombia & 0 & 0 & $1-4$ & $60-66$ & $1-4$ & $60-66$ \\
\hline Costa Rica & 1 & 7 & 0 & 26 & 1 & 33 \\
\hline India & 5.50 & 5.50 & 0 & $3-12$ & 5.50 & 5.50 \\
\hline Indonesia & $2-10$ & $5-10$ & 0 & $102 /$ & $12-20$ & $15-20$ \\
\hline Korea & $4-5$ & $23-27$ & 0 & 0 & $4-5$ & $23-27$ \\
\hline Malaysia & 0 & 0 & 2 & $5-12$ & 2 & $5-12$ \\
\hline Mexico & 10 & 10 & 15 & 39 & 25 & 49 \\
\hline Nigeria & 3 & 35 & 0 & 0 & 3 & 35 \\
\hline Pakistan & 2 & $12-253 /$ & 0 & 27 & 2 & $39-52$ \\
\hline Peru & 0 & 0 & 5 & 43 & 5 & $434 /$ \\
\hline Philippines & 2 & 10 & 0 & $23-32$ 2/ & 2 & $33-42$ \\
\hline Poland & $5-8$ & $10-16$ & 0 & 0 & $5-8$ & $10-16$ \\
\hline Russia & 6 & $6-14.50$ & 0 & 15 & 6 & $21-29.50$ \\
\hline Saudi Arabia & 0 & 0 & 0 & 9 & 0 & 9 \\
\hline South Africa & $7-16$ & $19-21$ & 0 & 10 & $7-16$ & $29-31$ \\
\hline Taiwan & 0 & 0 & 0 & 10 & 0 & 10 \\
\hline Thailand & 0 & 0 & $1-10$ & 12 & $1-11$ & 12 \\
\hline Turkey & $1-3$ & $7-18$ & 0 & 0 & $1-3$ & $7-18$ \\
\hline Ukraine & 1 & $1-5$ & $2-3$ & $10-15$ & $3-4$ & $11-16$ \\
\hline Venezuela & 1 & 0 & 0 & $30-37$ & 1 & $30-37$ \\
\hline
\end{tabular}

Source: IATA (2005a).

1/ Applies to U.S. and Canadian citizens only.

2/ Applies to domestic citizens only.

3/ Rate differentiated by class of travel.

4/ Includes both arrival and departure tax. 
have several different charges of either type (some of which are called "passenger service charges"), and so it is not always clear to which of these two categories the charge should be allocated. To the extent that airport charges diverge from being simple user fees, the economic effects on travelers of the two would in any event be similar. Given the difficulty of distinguishing between the two sets of charges - and their potential equivalence - the sum of the two, shown in the right-most columns of Tables 4 and 5, is thus of particular relevance.

Per passenger charges are clearly commonplace, though practice varies widely. Some countries have departure and/or arrival taxes only on foreigners, and some only on domestic residents or citizens; some differentiate charges by traveler class. In some high-income countries, current charges are substantial (highest of all in the United Kingdom, at US\$109 for first-class travelers to destinations outside of the EU). Most important for present concerns is that these charges are typically higher for international than for domestic travel (presumably reflecting the lower weight attached to the welfare of international passengers, or to their higher willingness or ability to pay taxes). ${ }^{16}$ And in some emerging market and developing countries (such as Colombia, Mexico, Pakistan, and Peru) charges for international travelers are at or above the highest levels in any high-income countries.

Whatever the underlying motive, this differentially heavier taxation of international trips will tend to offset, to some degree and in some countries, the inefficiencies implied by the relatively advantageous treatment of international aviation with respect to ticket taxes and aviation fuel. Most of the countries that have particularly high rates account, however, for a relatively small proportion of global aviation traffic. Those emerging markets (such as China, India, and several East Asian countries) that are larger in international aviation markets tend to have low rates. And in high-income countries, the offset is small except for a few that are, however, important in international aviation: Japan, the United Kingdom (mainly for high-end passengers on international routes), and, to some degree, the United States.

\section{ENVIRONMENTAL AND OTHER EXTERNALITIES}

A key argument in favor of taxing aviation (though not the only one) is that it generates various adverse environmental externalities. Even in the absence of any need for revenue (at least so long as any revenue raised can be put to a useful enough purpose), there may then be a case for a corrective aviation tax. More precisely, what is potentially most relevant here is

\footnotetext{
${ }^{16}$ Interestingly, and somewhat puzzlingly, this runs counter to the impression formed above that the ticket taxes levied in low income countries are commonly higher for domestic than for international travel. It may be that some low-income countries may find it more convenient to place additional charges on international passengers directly upon departure, rather than upon ticket issue.
} 
the nature and extent of environmental damage from international aviation: purely domestic damage from domestic aviation can in principle be dealt with, at least for the most part, by countries unilaterally, even given the legal obligations described above.

This section describes the main environmental and other externalities at issue.

\section{A. Air Pollution}

The main polluting substances in the emissions from burning aviation fuel are nitrous oxide $\left(\mathrm{NO}_{\mathrm{x}}\right)$, carbon monoxide $(\mathrm{CO})$, hydrocarbons, sulphates, and soot aerosols. There have been few attempts, however, to quantify effects: Friedrich and Bickel (2001) discuss the issue for Europe; estimates for Britain by Pearce and Pearce (2002) will be discussed and made use of below. A complicating factor is that some of these emissions, such as $\mathrm{NO}_{\mathrm{x}}$, affect the concentrations of other substances such as ozone and methane through rather complicated chemical processes; both the latter are pollutants and serve as greenhouse gases.

For ozone, the impacts are somewhat contradictory overall: at ground level, ozone is a pollutant which increases morbidity and mortality and reduces plant growth; at higher altitudes, it provides beneficial protection against ultraviolet radiation. The most careful studies of this are for Europe, ${ }^{17}$ but seek only to quantify ground-level effects. Note also that while $\mathrm{NO}_{\mathrm{x}}$ serves to increase ozone, other emissions from aviation fuel (sulfates and water vapor at higher altitudes) reduce it. The net effect is currently uncertain.

General air pollution effects from aircraft vary with location. Local pollution from aviation activity is obviously more damaging when the flight activity occurs near population centers. Aircraft emissions per distance traveled are also greater in the vicinity of airports. In particular, soot emissions are higher by a factor of 10 (per unit of fuel burned) at take-off than in regular flight, and CO and hydrocarbon emissions also substantially higher. ${ }^{18}$ Since many more international than domestic flights are long and over sea or deserted land areas, domestic aviation on average involves greater negative air pollution externalities (per unit of burned fuel) than international activity. Again, however, relatively little is known on the quantitative importance of these effects.

\section{B. Global Carbon Emissions}

Burning aviation fuel, like other fuels, contributes to a potential greenhouse effect through the emission of carbon dioxide $\left(\mathrm{CO}_{2}\right)$. At present, aviation accounts for only about

\footnotetext{
${ }^{17}$ Friedrich and Bickel (2001).

${ }^{18}$ Friedrich and Bickel (2001).
} 
3-4 percent of global carbon emissions. But the expectation is for a steady increase in this share, reflecting projected growth in aviation activity relative to other economic sectors. One base scenario in the projections of the Intergovernmental Panel on Climate Change ${ }^{19}$ is that by 2050 aviation is likely to contribute 5 percent of carbon emissions, and possibly as much as 15 percent.

\section{Other Emissions Affecting Global Warming}

Other polluting substances emitted by airplanes may also contribute to global warming. Their overall effect on climate is complicated and not fully understood. Substances contributing to climate effects are nitrogen oxides, methane, water vapor, sulfates, and soot. Some have substantial local components, and in some cases even the signs of the effects are uncertain. Effects also depend on the altitude of emissions and on whether the airline activity is subsonic or supersonic.

The main (non-carbon) climate-affecting emissions from subsonic air transport, at altitudes below $13 \mathrm{~km}$, are $\mathrm{NO}_{\mathrm{x}}$, water vapor, sulfates, and soot aerosols. $\mathrm{NO}_{\mathrm{x}}$ by itself has a complicated effect, increasing ozone, as noted above (which tends to increase global warming) but reducing methane (reducing global warming). The IPCC's assessment is that the former effect is the more important, pointing to a net increase in global warming - but with a large degree of uncertainty. Increased water vapor is less important, since it is released from the atmosphere within about two weeks. More soot tends to warm and more sulfates to cool the earth's surface, but here too there is great uncertainty.

The IPCC's best estimate of the contribution of aviation to overall radiative forcing ${ }^{20}$ -reflecting both carbon and non-carbon emissions-was about 3.5 percent in 1992. In the mid-range reference scenario, this increases to 5 percent in 2050, with an absolute radiative forcing effect of 3.8 times the 1992 value (with an upper possibility of about 15 percent). ${ }^{21}$

For supersonic aviation at altitudes of $17-20 \mathrm{~km}$-not a commercial proposition for the moment, but also not to be ruled out for the coming decades - global warming effects are far

\footnotetext{
${ }^{19}$ This estimate is from IPCC (1999), as are the others in the paragraphs that follow.

20 "Radiative forcing" refers to the net heating of the earth's surface induced by human activity (that is, the overall global warming effect). Between 60 and 70 percent of the net increase in radiative forcing is currently due to carbon emissions, and the rest to increased accumulation of other greenhouse gases such as methane, ozone, and clorfluorocarbons.

${ }^{21}$ These estimates assume no supersonic civil air transport by 2050 .
} 
more serious than for subsonic transport. ${ }^{22}$ The current IPCC estimate puts the effect per unit of fuel consumption at about 5 times greater.

\section{Noise}

Most noise pollution from subsonic aviation activity arises near or at airports, with damage varying greatly by airport location and nearby population density. Noise problems far from airports are small, at least for (subsonic) jet flight at 10-12 km (Pearce and Pearce, 2002). ${ }^{23}$ Noise pollution is thus an essentially local phenomenon, which countries can in principle deal with unilaterally by appropriate charges (though it is far from clear that they always do so).

\section{E. Pollution and Congestion at Airports}

Pollution at airports (apart from that caused by the burning of jet fuels) includes local and groundwater contamination due to use of de-icing fluids, local oil spills, and other substances used for clearing or cleaning runways. These externalities again do not involve cross-border spillovers, however, and so can in principle be corrected at the national level.

Congestion at airports can be said to consist of two separate components. First, there may be congestion in the air transport system, on runways and in airspace. Second, overcrowding of passengers may cause congestion in terminals, airport transport systems, and parking. This problem is usually of a peak-load character and may be particularly serious when scaling up of airport size (in terms of terminal, parking, and runway space) is difficult. With a single monopoly provider of air services, congestion externalities will tend to be fully internalized by the monopolist. ${ }^{24}$ When several airlines operate at a given airport, however, full internalization will generally not materialize, and congestion charges should be levied, typically at higher rates the more intense the competition. ${ }^{25}$ In relatively few cases, a single provider (or cooperating provider group) is totally dominant in any given major airport; thus internalization cannot generally be presumed.

\footnotetext{
${ }^{22}$ This is because: (1) $\mathrm{NO}_{\mathrm{x}}$ has a greater positive effect on ozone concentrations at such higher altitudes, and ozone a greater radiative forcing effect, and (2) water vapor emitted at high altitudes is accumulated to a much larger degree. Once again, the overall magnitude of these effects is uncertain.

${ }^{23}$ Supersonic transport creates local noise problems similar to those of subsonic transport, but far greater nonlocal noise problems over populated land areas.

24 See Acemoglu and Ozdaglar (2005) and Brueckner (2002).

${ }^{25}$ In Brueckner (2002), with airlines operating as Cournot oligopolists, the optimal toll equals the product of the congestion cost from an extra flight and unity minus the carrier's flight share at the airport).
} 
Congestion due to passenger overcrowding at or near airports is of little relevance to the case for international aviation taxes, since such externalities can be corrected by purely domestic means such as road user charges or other charges on road transport.

In principle, local airport administrative bodies should deal with externality costs arising at airports by charging such costs to users (airlines and/or passengers) through take-off and landing fees (preferably graduated by airplane size, fuel consumption, and local noise created by airplanes) and other congestion-related charges (such as fees for local parking and for the use of terminals charged to passengers, and peak-load fees charged to airlines). Most airports do indeed charge substantial fees. Only the fees in excess of the costs of constructing and operating airports can serve to correct for externalities. It remains unclear, however, whether fees are indeed set at such a level, and indeed this may well vary across countries and airports. ${ }^{26}$ To the extent that it is deemed as irremovable government failure, however, it may impact the design of coordinated policy.

\section{Taxing International Aviation: Basic Principles}

As a first step in thinking through the design of optimal aviation taxes, this section explores a simple model of aviation taxation that captures the motivation for levying such a tax as a means of both enhancing revenue and addressing border-crossing environmental externalities. The general framework is intended to capture in a simple way the key distinction between a tax on aviation fuel as a tax on an intermediate input, and ticket (or trip) taxes as a tax on final consumption.

The analysis starts with the case in which environmental damage does not cross bordersand, as throughout this section, there is no international mobility of any part of the tax baseso that the optimal policy of each country can be examined in isolation.

\section{A. No Cross-Border Damage}

Output $X$ (which might be thought of as passenger miles) is taxed at a specific rate of $\tau$. There is perfect competition, so that this is equivalent to (but analytically easier than) an ad valorem tax. For brevity, $\tau$ is referred to as a ticket tax, though it is clear that in the present simple setting - with only one, fixed type of journey - it is equivalent to a "trip tax." Output

\footnotetext{
${ }^{26}$ ICAO (2001) data suggest that, for most airports, airport fees and charges (as reported in Tables 4 and 5) are lower than construction and operation costs. On the other hand, IATA (2005b) concludes that in the United Kingdom, Germany, and France the overall level of charges and taxes on passengers and airlines exceeds the overall infrastructure costs of the sector, not including externality costs.
} 
is produced under constant returns, with unit cost $c(p+t)$, where $p$ denotes the price of fuel excluding the tax (taken to be exogenous) and $t$ a fuel tax in specific form. By standard results, the cost function $C$ is convex, with the use of fuel per unit output, $f$, given by

$$
c^{\prime}(p+t)=f
$$

and the curvature $c^{\prime \prime} \leq 0$ indicates the ease of substitution between fuel and other inputs. The consumer price of the final output is $Q \equiv \tau+c(p+t)$.

The object of policy is then to choose the two tax rates, $\tau$ and $t$, to maximize welfare, given by

$$
W \equiv V(Q)+\delta\left[\tau X(Q)+t X(Q) c^{\prime}(p+t)\right]-E\left(X(Q) c^{\prime}(p+t)\right)
$$

where the indirect utility function $V$ captures utility from private consumption, $\delta$ is discussed shortly, environmental damage $E$ is taken to be an increasing and convex function of overall aviation fuel use, and use has been made of (1) to rewrite fuel tax revenues $t F$. The parameter $\delta$, which plays a key role in the analysis, represents the marginal social cost of raising revenue (to which the marginal benefit of public expenditure will optimally be equated), and enables one to capture in convenient summary form the extent of the deadweight losses associated with the wider tax system that is not explicitly modeled. With lump-sum taxation, there are no such distortions and $\delta=1$. More generally, to the extent that distorting taxes must be used, $\delta>1$ : if this were not the case, it would be socially preferable to raise no tax revenue at all.

The necessary conditions for this problem are:

$$
\begin{gathered}
\frac{\partial W}{\partial \tau}=-X+\delta\left(X+\tau X^{\prime}+t c^{\prime} X^{\prime}\right)-E^{\prime} c^{\prime} X^{\prime}=0 \\
\frac{\partial W}{\partial t}=-c^{\prime} X+\delta\left[\tau c^{\prime} X^{\prime}+c^{\prime} X+t c^{\prime \prime} X+t\left(c^{\prime}\right)^{2} X^{\prime}\right]-E^{\prime}\left(c^{\prime}\right)^{2} X^{\prime}-E^{\prime} c^{\prime \prime} X=0,
\end{gathered}
$$

use being made of Roy's identity. Solving (3) and (4) to characterize the optimal tax rates, note that the system has determinant $D=X X^{\prime} c^{\prime \prime}$ : if $c^{\prime \prime}=0$, so that there is no substitutability between fuel and other inputs, then the two tax instruments are equivalent. When $c^{\prime \prime}<0$, the optimal fuel and (ad valorem) ticket taxes are characterized by, respectively: 


$$
\begin{gathered}
t=\frac{E^{\prime}}{\delta} \\
\frac{\tau}{Q}=\left(\frac{\delta-1}{\delta}\right) \frac{1}{\varepsilon}
\end{gathered}
$$

where $\varepsilon \equiv-X^{\prime} Q / X>0$ denotes the price elasticity of final demand (in absolute value).

There is thus a clear separation in the roles of the two taxes: environmental damage enters only the characterization of the fuel tax; while revenue considerations drive the ticket tax, which has the standard form of a Ramsey tax in the absence of externalities. To see his separation clearly, suppose that $\delta=1$, so that the revenue-raising motive vanishes. In this case optimal policy is simply to set the fuel tax at the Pigovian level and not to tax tickets at all. On the other hand, if, at the opposite extreme, there is no environmental damage $\left(E^{\prime}=0\right)$ then it is optimal to use only the ticket tax, setting the fuel tax to zero. The intuition here is straightforward. Aviation fuel is an intermediate input. Thus, by the Diamond-Mirrlees theorem, in the absence of externalities it should not be taxed at all if there are no constraints on the taxation (through the ticket tax) of final consumption. Put more loosely, the fuel tax is directly targeted on the externality and so should be given the sole responsibility of correcting it. When there is no environmental damage, on the other hand, a fuel tax serves only to reduce the effective tax base by distorting input choices and so leading to an unnecessary increase in the producer price faced by the airline.

Note, however, that whenever $\delta>1$, the (second-best efficient) correction of the externality is in an important sense incomplete. Unless lump-sum taxation is available, the environmental charge is set below the Pigovian level. This may seem surprising but is a standard result with a straightforward intuition: increasing the add-on towards the Pigovian level would lead to a reduction in the tax base, and hence revenues, that more than offsets the benefit derived from a reduction in the external damage. Thus the fuel tax component tends to be lower the greater the need for revenue (that is, the higher is $\delta$ ), whereas the ticket tax is increasing in $\delta .^{27}$

One further implication of these results should be noted: it is always possible to raise more revenue with the ticket tax than under the fuel tax. This follows on noting that the necessary conditions for maximizing revenue $T=\tau X(Q)+t X(Q) c^{\prime}(p+t)$ are

\footnotetext{
${ }^{27}$ Here, for simplicity, it is assumed that marginal environmental damage and the elasticity of demand are constants.
} 


$$
\begin{gathered}
\frac{\partial T}{\partial \tau}=X+\tau X^{\prime}+t c^{\prime} X^{\prime}=0 \\
\frac{\partial T}{\partial t}=\tau c^{\prime} X^{\prime}+c^{\prime} X+t\left(c^{\prime}\right)^{2} X^{\prime}+t c^{\prime \prime} X=0
\end{gathered}
$$

which together imply $t c^{\prime \prime} X=0$, and thus $t=0$ for $c^{\prime \prime}<0$.

Given the evident difficulty of implementing any indirect tax on international aviation, let alone two, the case in which only one can be levied is of natural interest. The optimal levels of each tax when used in isolation are readily derived from (3) and (4) above, being

$$
\frac{\tau}{Q}=\left(\frac{\delta-1}{\delta}\right) \frac{1}{\varepsilon}+\frac{E^{\prime} c^{\prime}}{\delta Q}
$$

for the ticket tax, and

$$
\frac{t}{p+t}=\left(\frac{\delta-1}{\delta}\right) \frac{1}{(1-\alpha) \sigma+\alpha \varepsilon}+\frac{E^{\prime}}{\delta(p+t)}
$$

for the fuel tax, where $\sigma$ denotes the elasticity of substitution between fuel and a composite other input in producing air travel, and $\alpha$ the share of fuel in total costs. Clearly the neat separation of roles found when both taxes can be used is now lost: each is shaped according to both revenue and environmental concerns, and indeed the two possess the same additive structure. ${ }^{28}$ The key difference between the two is that whereas the ticket tax depends on the elasticity of demand, the optimal stand-alone fuel tax depends on a weighted average of the elasticity of demand and the elasticity of substitution. If there is no possibility of substituting away from fuel use, then the optimal stand-alone fuel tax per unit of final output, $t c^{\prime}$, is identical to the stand-alone ticket tax, $\tau$. In contrast, when $\sigma>0$ and there are substitution possibilities between factors, the fuel tax is lower, by an extent that increases with the strength of substitution in production and decreases with the elasticity of final demand. In the absence of strong demand responses, revenue will thus also be less under the fuel tax. Intuitively, the distortion of production decisions creates a reason to moderate the level of taxation that does not arise under the ticket tax, and by the same token - as noted aboveerodes the ultimate revenue base.

\footnotetext{
${ }^{28}$ This is reminiscent of Sandmo's (1975) result on the additivity of Ramsey and environmental terms in optimal commodity taxes on final products (which itself recurs below when considering cases where only one of these tax instruments is deployed).
} 
Which then of the two instruments - ticket tax or aviation fuel tax - should be chosen if only one can be deployed? From the preceding discussion, it is clear that the choice hinges on the relative importance of environmental and revenue concerns. All else equal, the ticket tax is more likely to be the preferred instrument, the greater is the need for revenue and the lower is marginal environmental damage.

\section{B. Implications of Cross-Border Damage}

Allowing now for the border-crossing environmental damage that is a key element of the potential rational for international aviation taxes, a central distinction arises between cooperative and non-cooperative tax-setting.

\section{Cooperative taxation}

Suppose now that the environmental damage crosses international borders (and, for simplify, that there are only two countries) with that suffered by country $i$ being, in obvious notation, $E_{i}\left(X_{1} f_{1}+X_{2} f_{2}\right)$. Welfare in country $i$ thus becomes:

$W_{i} \equiv V_{i}\left(Q_{i}\right)+\delta_{i}\left[\tau_{i} X_{i}\left(Q_{i}\right)+t_{i} X_{i}\left(Q_{i}\right) c_{i}^{\prime}\left(p+t_{i}\right)\right]+E_{i}\left(X_{1}\left(Q_{1}\right) c_{1}^{\prime}\left(p+t_{1}\right)+X_{2}\left(Q_{2}\right) c_{2}^{\prime}\left(p+t_{2}\right)\right)$

where, note, the countries may differ in preferences and/or technology. Suppose first that countries cooperate in setting their tax rates, in the sense that each seeks to maximize $W_{1}+W_{2}$. Thus, in particular, each country takes account of the impact that its tax choices have on the other country through the environmental harm it causes the other side of the border. In this case, it is easy to show that the optimal taxes are

$$
\begin{gathered}
t_{i}=\frac{E^{\prime}}{\delta_{i}} \\
\frac{\tau_{i}}{Q_{i}}=\left(\frac{\delta_{i}-1}{\delta_{i}}\right) \frac{1}{\varepsilon_{i}}
\end{gathered}
$$

where $E^{\prime} \equiv E_{1}^{\prime}+E_{2}^{\prime}$ now denotes the sum of the environmental damages that the two countries suffer from a unit increase in international travel. The key point here is that even though the Pigovian marginal social damage that enters the optimal fuel tax expression is the same in the two countries - because it reflects their collective harm - the optimal fuel tax is typically not the same in the two countries. Reflecting the considerations discussed above, it is lower in the country with the higher marginal cost of public funds. This may at first seem 
counterintuitive, but reflects the same logic as above: the environmental component is lower to mitigate the impact through pre-existing distortions, with the greater need for revenue reflected instead in a higher tax on the final product. As one would expect, the optimal ticket tax is higher when the country-specific value of $\varepsilon_{i}$ is lower (when aviation demand responds less to changes in aviation prices), for given $\delta_{i}$. More generally, then, even when countries cooperate fully, it will typically be optimal for them to set different taxes, both to exploit differences in elasticity of demand and to reflect their differing needs for government revenue.

\section{Noncooperative taxation and the gains from coordination}

More plausibly, current aviation tax policy implies that countries in most cases do not cooperate but rather look to their own national interest: country $i$ simply maximizes $W_{i}$. In this case each country takes as given the tax rates set by others, with equilibrium noncooperative tax rates:

$$
\begin{gathered}
t_{i}=\frac{E_{i}^{\prime}}{\delta_{i}} \\
\frac{\tau_{i}}{Q_{i}}=-\left(\frac{\delta_{i}-1}{\delta_{i}}\right) \frac{1}{\varepsilon_{i}}
\end{gathered}
$$

Thus when both taxes are used in the pursuit of national rather than collective interest, equilibrium fuel taxes reflect only the harm that each country perceives for itself, and so are set lower than in the cooperative outcome. The characterization of the ticket tax, on the other hand, remains exactly as in the cooperative case. ${ }^{29}$

That the neglect of harm suffered abroad leads to fuel taxes being set at inefficiently low levels is evident enough, and easily verified: starting from a non-cooperative equilibrium, both countries would benefit from a coordinated increase in fuel taxes. ${ }^{30}$

\footnotetext{
${ }^{29}$ The precise value will differ, reflecting the impact of the different level of the fuel tax on producer prices and hence, in principle, on the elasticity of demand.

${ }^{30}$ For example, a small increase in $t_{1}$ from the non-cooperative equilibrium has no effect on $W_{1}$ (as an envelope property) but increases $W_{2}$ by $-E_{2}^{\prime}\left(X_{1}^{\prime}\left(c_{1}^{\prime}\right)^{2}+X_{1} c_{1}^{\prime \prime}\right) d t_{1}>0$.
} 
It is readily shown that ticket taxes also tend to be set too low in non-cooperative equilibrium: a small increase in country 1 's ticket tax $\tau_{1}$, for example, has no first-order effect on welfare in country 1 (as an envelope property) increases welfare in country 2 by $-E_{2}^{\prime} X_{1}^{\prime} c_{1}^{\prime} d \tau>0$. The existence of this inefficiency in ticket taxes may seem strange, given that the characterization of these taxes in the non-cooperative equilibrium (equation (15)) is exactly the same as in the cooperative solution (13) - indeed if the elasticity of demand are constant, the numerical level of the ticket tax is precisely the same in the non-cooperative equilibrium as under full cooperation. The point here is that unless fuel taxes are set to deal appropriately with the environmental damage, then moving ticket taxes away from the cooperative rule (or even level) may be desirable as a second-best means of reducing emissions.

While the analysis thus points to potential coordination gains in respect of both ticket and fuel taxes, those in respect of the latter are in an important sense more fundamental and a more appropriate focus of policy: increasing ticket taxes may convey a mutual benefit for the reason just noted, but is also likely to move those taxes away from their appropriate cooperative levels. Increasing fuel taxes from their non-cooperative levels, on the other hand, is likely to bring them closer to their cooperative levels, in the process eliminating any gain from ticket tax coordination and moving the combination of instruments towards the efficient outcome.

The magnitude of the coordination gains will depend on the nature and extent of asymmetries between the countries. It may be greater the more similar are the countries (or the less significant any one country is): for if, in contrast, one country causes a large share of overall externalities, then it will to a large degree internalize these in its own decision-making. The situation in respect of the ticket tax, however, is entirely different. In this case, given that both the fuel tax and the ticket tax are used simultaneously, there is no coordination gain since the ticket tax does not generate any cross-border externalities.

\section{Treatment of Business and Economy Travel}

The analysis above treats air travelers as a homogeneous group. In reality, of course, the aviation market is highly segmented, between (and to some degree within) first, business, and economy class. In terms of aviation fuel taxes, it is likely to be impractical to distinguish between them - and also undesirable, if the sole purpose of the tax is to address externalities associated with fuel use. The question is whether it is desirable to distinguish between them in terms of ticket or trip taxes.

Importantly, the elasticity of demand $\varepsilon-$ a key component of the tax rules developed above - may well be very different in the different segments, suggesting that optimal tax 
rates may well differ between them. A recent survey of the evidence ${ }^{31}$ concludes that business travelers' demands are typically far less responsive to price than economy or tourist travelers': empirical results vary considerably, but suggest central estimates of the demand elasticity (in absolute value) for business travel of around 0.25 for long-haul international travel, around 0.6 for short-haul domestic travel, and for economy-class travel of around 1.0 (long haul) and 1.3 (short haul). ${ }^{32}$ The analysis above would thus point to substantially higher ticket or trip taxes on business than on economy-class travel.

There are though other considerations that temper this conclusion:

- $\quad$ To the extent that consumers substitute between classes of travel, differentiation runs the risk of creating further and unnecessary distortions of their choice of class of travel. Now this effect is likely small, since the changes in ticket prices due to possible aviation taxes are likely to be quite small relative to the differences in average prices between classes.

- Interactions with the wider tax system are potentially important. In particular, to the extent that this wider system induces consumers to take more leisure (in the broad sense of time out of the labor market) than would otherwise be the case, optimal tax design involves seeking to counteract this effect by taxing more heavily those items that are more complementary with leisure. To the extent that economy travel tends to be for leisure and business travel for business, this points in the opposite directionto a lower tax on business- than economy-class travel. ${ }^{33}$

- To the extent that business class travel is an input into production, the Diamond-Mirrlees theorem suggests that it ought not to be taxed at all, at least if fuel is properly taxed. This result has full force in cases where tax revenue is the only concern: taxing a business input would lead to such a reduction in output that any revenue gained by the tax itself would be more than offset by a reduction in the revenue that could be raised by other taxes (such as those on salaries, profits, or final sales).

Where the balance of these considerations lies is not clear-cut. Business travel may to some degree be an item of final consumption, for example; and not all economy-class travel is for leisure. The natural conclusion is that there is no overwhelming reason to differentiate

\footnotetext{
${ }^{31}$ Gillen, Morrison, and Stewart (2004).

${ }^{32}$ European Commission (2005a, 2005b) takes a central estimate of -0.5. Earlier work by the ICAO (1985) implies a demand elasticity for leisure trips of -1.1 for short-haul trips, and -0.8 for long-haul trips.

${ }^{33}$ Strand (2005a) develops this argument in detail.
} 
between business and economy travel, and that the best form of ticket tax would in principle be a VAT, creditable to registered taxpayers (subject to the usual controls to deny credit for private use).

\section{THE IMPLICATIONS OF NON-ENVIRONMENTAL DISTORTIONS IN INTERNATIONAL AVIATION}

The analysis in the previous section focused on environmental damage as a key motivation for levying indirect taxes on aviation. But such damage is not the only possible source of failure in the market for aviation. This section considers other possible distortions and their implications for the design of aviation taxes.

\section{A. International Tax Competition}

As noted above, countries may be unable or unwilling unilaterally to levy aviation taxes at levels they feel likely to reduce their competitiveness - and hence revenue raised, market share of their own airlines and airports in world markets, or of their tourism industriesgiven the taxes charged by other countries. It is possible, for example, for parts of the airline business to change their location, in particular those parts that involve air routes with more than one leg, by rescheduling routes and altering the hub structure in response to differential taxes between countries and individual airports. In the case of fuel taxes, they may choose to bunker in lower tax jurisdictions, which is likely to be a serious problem when fuel tax rates differ substantially (see the discussion below) but less so when they differ by margins of the size considered here. All this points - for reasons that are familiar, for example, in relation to the taxation of internationally mobile capital ${ }^{34}$ - to non-cooperative taxes on international aviation being set at an inefficiently low level and to scope for mutually beneficial gains from a coordinated increase. This, it should be stressed, is a quite distinct source of gain from cooperative taxation from that relating to border-crossing externalities explicitly modeled above.

There are some qualifications to this presumption of mutual gain from coordination. First, there may be countervailing incentives to set tax rates higher than the level that is in the collective interest, in order to exploit power in world markets. Countries with strong appeal to tourists, or with major airports serving as hubs, may to some degree exploit these advantages by "tax exporting," imposing high taxes on foreigners whose welfare is presumably valued less than that of domestic residents. Indeed, that is presumably to some degree the rationale for the heavier departure and ticket taxes on international travel

\footnotetext{
${ }^{34}$ A classic reference is Zodrow and Mieszkowski (1986).
} 
described above, at least for some lower-income countries. But, as also argued there, these do not seem to be the dominant considerations in setting aviation taxes.

Second, the interests of countries diverge, and it is possible that coordinated tax increases can be made beneficial to all only if some of the revenue raised is used to compensate those who would otherwise lose. Indeed, coordinated tax increases by a subset of countries may increase the benefits of non-cooperation to other countries. ${ }^{35}$

Moreover, most flight activity (the moving of passengers and cargo to and from particular destinations) cannot be readily rescheduled on a large scale, as it must serve the populations naturally catering to the respective airports, and is thus not very mobile. Strategic international fuel tanking is likely to be a problem only given very high aviation fuel taxes, not with the moderate taxes currently under discussion. ${ }^{36}$ In Norway, for example, when an aviation fuel tax at a rate of 16 U.S. cents per gallon was first proposed (a tax rate close to the most relevant alternatives under consideration here), major airlines threatened to purchase substantial excess aviation fuels abroad. Such a fuel tax was enacted in 1999, and has since been increased moderately, to about 18 U.S. cents per gallon. In fact little or no such excess fueling has taken place. ECON (2005), discussing this case, concludes that the low level of the tax made excess tanking abroad uneconomical, due to resulting excess plane weights. Nevertheless, experience in relation to tanking of commercial diesel fuel in the EU-for which there is significant evidence of tax competition (Evers, de Mooij, and Vollebeergh (2004)) - suggests that this could become a real issue at the higher of the levels of international fuel tax currently under discussion. ${ }^{37}$

\section{B. Imperfect Competition}

Imperfections of competition in the aviation sector create another corrective consideration in the setting of aviation taxes, affecting their optimal level and form.

\footnotetext{
${ }^{35}$ For elaboration of these points, albeit in contexts somewhat different from the present, see Kanbur and Keen 1993) on the possibility of Pareto gains from harmonization or the adoption of a minimum tax rate and Konrad and Schjelderup (1998) on the possibility of a subset of countries gaining from coordination in which others do not participate.

${ }^{36}$ Edmondson et al (2005), considering a fuel tax rate of about US\$1 per gallon within the EU area alone (about five times the level considered here), calculate that 50 percent or more of the fuel tax base may then be lost for inter-EU air traffic. Another study by the European Commission (1999) however concludes that the loss of the aviation fuel tax base will be only 5-10 percent for tax rates in this range; this study however only considers taxes on domestic aviation fuels for which the cost of bunkering abroad will clearly be greater.

${ }^{37}$ See also Edmondson and others (2005).
} 
In standard cases of homogenous product monopoly or Cournot competition, the first-best policy_leaving revenue and environmental considerations aside for the present - is an output subsidy set so as to induce marginal cost pricing, combined with lump-sum transfers to firms, if necessary, to ensure non-zero profits. Combining this with revenue and environmental concerns, the implication is of taxes optimally lower than would otherwise be the case. ${ }^{38}$

Aviation, however, is characterized by multiple and heterogeneous products and firms. It involves several submarkets, most notably those for economy and business/first-class travel. Products are differentiated along several dimensions, such as flexibility of booking, availability at short notice, travel and airport comfort, food and entertainment service, connection availability, and timing. The potential importance of such differentiation is illustrated by the pricing structure of a fairly typical trans-Atlantic flight, with British Airways in 1998, shown in Table 6. Only 9 percent of passengers were in first or "club" (business) class, but they accounted for about 50 percent of revenues. ${ }^{39}$ There was wide price differentiation even within the "traveler" (economy) class segment. This differentiation may well have increased since 1998, by place of ticket issue, and by whether the ticket is sold through a travel agency, via the Internet, or directly from the airline. ${ }^{40}$ Some differentials may reflect cost differences, but some may also be due to more sophisticated price differentiation between passenger segments.

Such price discrimination is not in itself evidence that there are inappropriate output restrictions. In the presence of economies of scale and scope in offering these related products, marginal cost pricing may not suffice to cover costs. ${ }^{41}$

\footnotetext{
${ }^{38}$ See for instance Kolstad (2000, pp. 129-32).

${ }^{39}$ Effective price differences are often even wider, since quite a few first- and business-class travelers do not use the option of a return ticket for which they have paid, as pointed out by Hanlon (1999). More generally, for some major airlines business- and first-class passengers make up about 50 percent of gross revenues, even when comprising less than 15 percent of passengers. For other airlines specializing in low-cost travel, these shares are obviously less and for some close to zero. On a worldwide basis, our best current estimate is that business/ first-class customers account for approximately 30 percent of total airline revenue; see Table 8 .

${ }^{40}$ Kesharwani (2001) distinguishes three "standard" ticket classes (restricted economy, unrestricted economy, and premium) rather than the two usually identified (economy and premium), and also documents substantial further price differentiation within the restricted economy-class segment. (In Table 8, the APEX and Promotion tickets both belong to the restricted economy-class tickets).

${ }^{41}$ In a standard case with separately produced sub-products, with unrestricted entry in each submarket, underor over-pricing relative to cost in individual sub-markets is generally infeasible. Economy- and business-class travel, however, are often joint products. In such cases, differentiated prices between the two types of travel (and moreso than average variable production costs) may be compatible with free entry. As argued in
}

(continued) 
Table 6. Illustrative Seat Prices by Type of Ticket

(British Airways 747 London-New York, November 1998)

\begin{tabular}{lccccc}
\hline \multicolumn{1}{c}{ Travel Class } & $\begin{array}{c}\text { Ticket Price } \\
\text { Round Trip, } \\
\text { in GBP }\end{array}$ & $\begin{array}{c}\text { Number of } \\
\text { Seats }\end{array}$ & $\begin{array}{c}\text { Average } \\
\text { Capacity } \\
\text { Utilization } \\
\text { (In percent) }\end{array}$ & $\begin{array}{c}\text { Average Share } \\
\text { of Passengers } \\
\text { (In percent) }\end{array}$ & $\begin{array}{c}\text { Average Share of } \\
\text { Revenue } \\
\text { (In percent) }\end{array}$ \\
\hline First class & 5234 & 18 & 50 & 3 & 25 \\
Club class & 2954 & 25 & 60 & 6 & 24 \\
$\begin{array}{l}\text { Unrestricted } \\
\text { Traveler class }\end{array}$ & 844 & 49 & 80 & 15 & 18 \\
APEX class & 357 & 124 & 85 & 39 & 13 \\
Promotion class 1/ & 187 & 132 & 100 & 49 & 19 \\
Total & $1868132 /$ & 359 & 75 & & \\
\hline
\end{tabular}

Source: Hanlon (1999).

1/ The "Promotion class" is a particular low-price ticket sold as part of a time-limited promotion scheme and has been assigned a capacity utilization rate of 100 percent.

2/ Total revenue per flight.

Indeed, if sunk costs are zero and entry and exit perfectly free, then the weak invisible hand theorem of Baumol, Panzar, and Willig (1982) implies that the no-intervention outcome is constrained Pareto efficient, relative to the constraint that profits be non-zero. This result is highly sensitive to the assumption on sunk costs - results on the efficiency properties of contestable markets can be destroyed even by small sunk costs - but provides a useful benchmark for assessing the likely extent of monopolistic output restriction.

A key question is how free are entry and exit. This has been studied widely for domestic aviation in the United States, the general conclusion being that long-run profits have been

Transportation Research Board (1999) and Hanlon (1999), the assignment of fixed cost shares to the different segments is then in a sense arbitrary, and costs may be assigned in relation to willingness or ability to pay. A factor enabling airlines to maintain high prices for business-class passengers is that while entry of new airlines in the economy-class segment has proven to be relatively easy, entry of new actors has proven to be much more difficult in the business- and first-class segments. 
close to zero, and entry/exit relatively free, at least in the economy-class segments. ${ }^{42}$ Strassman (1990), for example, studying data from the late 1980s, found evidence of few direct barriers to entry of new airlines, and that actual (and not potential limit) price levels largely govern the entry of new operators. ${ }^{43}$ Both formal and informal barriers (the latter in particular due to the provision of subsidies to national airlines) have also been reduced further, with the wave of airline deregulation and privatization since the 1980s, at least in North America and Europe. ${ }^{44}$ Doganis (2001) however notes that over the period 1990-97, European airlines that at the time were under government majority control received collective public subsidies of more than US\$11 billion, while large private airlines collectively received more than US\$3 billion from their respective governments.

More important for present concerns is the ease of entry/exit on international routes. This appears to have been less systematically studied, though the stronger legal restrictions on entry, including for cabotage and third-country carriers (reflecting the continued desire to support and maintain national carriers), suggest that - while there is clearly considerable variation by route - there is in this context more likely to be some degree of monopolistic output restriction. ${ }^{45}$ Even here, however, few clear-cut conclusions emerge. There seems to be no evidence that private international carriers systematically earn supernormal profits, suggesting there are factors at work tending to offset price impacts through entry restrictions. On balance, there thus seems to be no clear presumption as to the impact of imperfections of competition on the level and composition of aviation output. The safest course for policy may then be to assume that there is none.

The existence of imperfect competition could also affect the relative efficiency of fuel and ticket taxes, insofar as the former is equivalent, as a first approximation, to a specific tax on travel. Under perfect competition (and in a homogenous product market - a restriction relaxed separately below), ad valorem and specific taxes are equivalent; under imperfect competition they are not, and it is a fairly robust result that ad valorem taxes are then socially

\footnotetext{
${ }^{42}$ See, for instance, Transportation Research Board (1999), Hanlon (1999), Borenstein (1989, 1991, 1992), Borenstein and Rose (1994), Evans and Kessides (1993), Hurdle and others (1989), Mayer and Sinai (2003), Morrison (2001), and Whinston and Collins (1992).

${ }^{43}$ See Reiss and Spiller (1989), Borenstein, (1989, 1991, 1992), and Whinston and Collins (1992), and more recently, Goolsbee and Syverson's (2005) study of preemptive effects of expected entry into particular routes.

${ }^{44}$ See Transportation Research Board (1999).

${ }^{45}$ For example, the crucial and lucrative Trans-Atlantic market, involving mainly European and North American carriers, is strictly regulated, with strong restrictions on existing carrier expansion or new carrier entry.
} 
preferable. ${ }^{46}$ This is because an ad valorem tax serves to mitigate oligopolistic output restriction, since part of the additional revenue firms would otherwise enjoy from increasing their price is taxed away (which is not the case under specific taxation), thus tending to leave prices lower than they would be under an equal-yield specific tax, increasing output, tax revenue and welfare.$^{47}$ In the presence of externalities related to the level of physical output, as in the case of aviation pollution, the balance might be expected to tip more in favor of specific taxation, since this is more directly tied to the extent of the externality. Indeed Pirttilä (2002) argues that specific taxation is preferable whenever the externality is sufficiently important relative to the monopolistic output restriction. This result depends, however, on an assumption that all the fixed amount of tax revenue required is to be raised from this single tax. ${ }^{48}$ If more plausibly, aviation taxes comprise a small fraction of overall tax revenue, then an ad valorem tax is always preferable on these grounds. ${ }^{49}$ Since the extent of imperfect competition is by no means clear, however, this implication too is likely to be of relatively minor consideration for tax design.

\section{Network Externalities}

A typical form that network externalities may take in the aviation industry is that a larger air traffic volume at a given airport expands passengers' air route choices. There are thus positive externalities from a larger traffic volume in a given airport, up to some limit. Such externalities may in principle offset some of the negative externalities listed above, or even argue for subsidies to air transport. In the transportation literature, the so-called Mohring effect indicates the average time saving of air passengers, traveling between two specific destinations, when aviation route networks expand..$^{50}$ Betancor and Nombela (2002) evaluate Mohring effects in European air transport. They find that the average air traveler, traveling between two European capitals, has had a reduction in total traveling time of 20 minutes from 1990 to 1998, due to more extensive and frequent flights. A main result is that the time reduction is largest for the routes with the lowest initial densities and is very small for initially dense routes (such that the gains essentially vanish for routes with traffic exceeding

\footnotetext{
${ }^{46}$ See for instance Delipalla and Keen (1992).

${ }^{47}$ Keen (1998) discusses this principle further, and shows that it holds also under particular classes of Bertrand competition (building on the Dixit and Stiglitz (1977) model).

48 The intuitive reason why Pirttilä (2002) finds specific taxation to be preferable when the environmental externality dominates is that the corrective ad valorem tax may raise more revenue than needed.

${ }^{49}$ Strand (2005b).

50 This effect, due to Mohring (1972), was originally discussed for bus networks.
} 
150,000 passengers/year). The upshot is that there are obvious efficiency gains to be reaped for air routes with low initial densities, but not for high-density routes.

Most airlines tend to limit own ticket issues to routes covered by the airline itself (including in some cases a limited range of cooperating partners) and to effectively exclude the routes of other airlines operating on the same airport. Such strategies serve to limit the scope for positive network externalities from greater traffic loads, and hence weaken any case for supporting output. In any event, the empirical magnitude of such externalities remains uncertain. Certainly, there is no strong evidence that this should be a major concern in designing aviation tax policy.

\section{Product Quality}

The mix between ad valorem (ticket) and specific (fuel or per passenger) charges may in principle affect product quality, which in turn affects the optimal balance between the two tax types. Broadly speaking, an ad valorem tax will induce airlines to compete in part by offering lower-quality products than otherwise. This is because such a tax requires the price to the consumer of any improvement in product quality to increase by more than the costs incurred in bringing about that improvement: with a ticket tax of 50 percent, for example, the price charged to the consumer would have to increase by US\$2 to cover a cost increase of US\$1. Thus relatively heavy reliance on ticket taxes (rather than, say, per passenger charges) is likely to imply lower than otherwise in-flight service and seating space, and less frequent flights with higher load factors (and hence less flexibility in booking).

How such quality effects impact the appropriate balance between specific and ad valorem taxes depends on the precise way in which it affects demand.$^{51}$ In general, taxes should be designed so as to avoid needless distortions of product quality, which points to relatively heavy reliance on specific taxation. One special case may be particularly important. To the extent that upgrading takes the form of reduced waiting times for passengers, its effect is analytically similar to that of a simple reduction in the price charged to consumers, reflecting the shadow value of their time. In this case, wholly specific taxation is optimal, at least when firms are perfect competitors.

Once again the significance of these considerations is likely to be limited at modest levels of taxation. The argument that emerges in favor of fuel taxes or departure taxes on grounds of product quality might reasonably be taken as simply offsetting any preference for ticket taxes as a consequence of tendencies to monopolistic output restrictions.

\footnotetext{
${ }^{51}$ For a general analysis, and the result for the special case mentioned shortly, see Delipalla and Keen (2005).
} 


\section{E. Distortions in Competing Modes of Transport}

Distortions in transport markets that provide substitutes for air travel may also impact the optimal structure of aviation taxes. In particular, since short-haul air travel often competes with road or rail transport, any over- or under-pricing in these sectors (taking account of any externalities associated with their usage) — to the extent that it cannot be addressed directlyshould be factored into aviation tax design. The extent of the proper adjustment depends on both the cross-elasticity of demand between aviation and these other modes and the direction of the distortion in the latter. To the extent that a competing mode is inappropriately subsidized, for example (and the subsidies cannot be removed), the optimal aviation tax will be lower than otherwise, in order to counteract the tendency towards socially excessive use of the alternative.

This consideration is potentially important in both North America and Europe. In much of North America, short-haul air transport competes mainly with car travel (though there are cases, notably on the eastern seaboard, in which it competes with rail); in Europe, air transport more commonly competes with rail. Recent work suggests that road transport is overtaxed in Europe and undertaxed in the United States and other countries where road vehicle fuel taxes are low (at least in urban areas where most airports are located).$^{52}$ If higher road traffic taxes in the United States are ruled out, then second-best aviation taxes will be lower there relative to the benchmark Pigovian case (though this is of course a matter for domestic tax policy rather than internationally coordinated taxes). In Europe, on the other hand, second-best considerations would point to a higher aviation tax than would otherwise be the case (including on international flights within the region). On the other hand, rail transport tends to be heavily subsidized in Europe (in particular in France, Germany, and the Benelux countries). ${ }^{53}$

For North America, this argument should tend to speak in favor of a lower optimal aviation tax. For Europe, the implications for optimal aviation tax rates are unclear. They depend on, for instance, the strength of substitutability between road, rail, and air transport, and cross-elasticities of road (and rail) traffic with respect to aviation fares. Overall, such second-best arguments suggest that aviation taxes generally ought to be higher in Europe than in North America. The strength of these considerations depends, however, on judgments as to the appropriate tax treatment of other sectors and a view that the superior policy of directly eliminating any such inefficiencies is for some reason unavailable.

\footnotetext{
${ }^{52}$ See Parry (2002), Parry and Bento (2001), and Parry and Small (2004). See also Singh (2004) for a discussion of optimal congestion charges in selected large cities in both developed and developing countries.

${ }^{53}$ IATA (2005b) documents substantial rail subsidies in Britain, France, and Germany.
} 


\section{F. Input Price Distortions}

Distortions also arise to the extent that airplane production and operation are subsidized by producing and operating countries' governments. To the extent that such subsidies are significant - a continued matter of contention between Airbus and Boeing - they point to relatively high aviation taxes.

Implicit taxes or subsidies will also arise to the extent that airport fees and charges differ from appropriate marginal cost levels. Such limited evidence as there is (as mentioned in footnote 27) suggests, tentatively and with exceptions, a broad tendency for high-income countries to subsidize such activities - pointing to higher aviation taxes - and for lowerincome countries to tax them. To the extent that this is the case, it is an argument for generally lighter aviation taxation in low-income countries than in high-income ones.

\section{RATES, REVENUE, AND INCIDENCE}

This section considers the rates at which internationally coordinated aviation taxes might be set, the revenue they could raise, and who would bear the burden imposed.

\section{A. Rates}

It was shown above that it is typically optimal to deploy both fuel taxes (addressed to environmental damage from emissions) and some form of ticket tax (motivated by revenue needs), with the appropriate rates of these taxes depending on the responsiveness of final demand, the pattern of environmental damage, the ease of substitution between fuel and other inputs, and the importance of the need for revenue. There is great uncertainty about all of these, including not least the marginal cost of public funds. ${ }^{54}$ By way of illustration, Box 3 reports simple calculations of optimal taxes under alternative assumptions for the elasticity of demand and marginal cost of public funds.

To abstract from these complications, however, the analysis that follows simply considers the implications of setting aviation taxes at levels that reflect the marginal global external damage from fuel consumption, $E^{\prime}$, and under the further simplifying assumption that within

\footnotetext{
${ }^{54}$ Estimates of $\delta$ for the United States, for example, range from a little over 1 to more than 2.
} 
Box 3. Optimal Aviation Tax Rates for Alternative Parameter Values

Assuming $E^{\prime}=\mathrm{US} \$ 0.2$ as in the text, application in (5) and (6) of alternative assumed values for the elasticity of demand and marginal cost of public funds implies the following tax rates:

\begin{tabular}{|l|c|c|c|c|}
\hline & \multicolumn{2}{|c|}{$\delta=1.2$} & \multicolumn{2}{c|}{$\delta=2$} \\
\hline & $\varepsilon=1.2$ & $\varepsilon=0.4$ & $\varepsilon=1.2$ & $\mathrm{E}=0.4$ \\
\hline $\begin{array}{l}\text { Fuel tax when used together } \\
\text { with ticket tax (US\$ per gallon) }\end{array}$ & 0.17 & 0.17 & 0.10 & 0.10 \\
\hline $\begin{array}{l}\text { Ticket tax when used together } \\
\text { with fuel tax (percent) }\end{array}$ & 14 & 41 & 42 & 125 \\
\hline
\end{tabular}

The tendency for the environmental tax to decrease and for the ticket tax to increase with the marginal cost of public funds $(\delta)$ is here quite marked.

the relevant range this is independent of the extent of aviation travel. ${ }^{55}$ For this purpose, the only estimates of external damage from aviation fuel of which we are aware are those of Pearce and Pearce (2002) for the United Kingdom. Summarized in Table 7, these point to a Pigovian tax around 6 G.B. pence per liter, or about 40 U.S. cents per gallon. Arguably, marginal aviation externalities may be higher than average in the United Kingdom (due to relatively high income and population densities there).

A figure of 20 U.S. cents per gallon might thus be taken as a (conservative) indicative figure for a global Pigovian tax $t$ on aviation fuel. ${ }^{56}$ With the current average jet fuel price in excess of US\$2 per gallon - and ignoring for the moment any improvement in fuel efficiency - this would imply an increase in fuel costs of about 10 percent.

\footnotetext{
${ }^{55}$ This is, of course, likely to be a lower bound on the tax likely to be optimal when revenue is a concern.

${ }^{56}$ There has been discussion of aviation fuel taxes in the EU context at much higher levels than those considered here. In November 1996, the European Commission recommended that excise duties on mineral oil, at the level of $245 \mathrm{ECU}$ per 100 liters, ought to be extended to aviation fuel as soon as the international legal situation allowed. Such a tax level on aviation fuels would be equivalent to about US\$1 per gallon (five times the level here considered in line with marginal environmental costs), and close to the current domestic aviation fuel taxes in the Netherlands and Japan.
} 
Table 7. Estimated Average Aviation Fuel Tax Necessary to Cover Main Externality Costs (Noise and Air Pollution)

(GBP per liter of aviation fuel)

\begin{tabular}{lccc}
\hline \multicolumn{1}{c}{ Airplane Type } & Noise Tax & Air Pollution Tax & Total Tax \\
\hline A310 & 0.01 & 0.05 & 0.06 \\
A340 & 0.01 & 0.06 & 0.07 \\
BAe146 & 0.00 & 0.05 & 0.05 \\
B737-100 & 0.06 & 0.04 & 0.10 \\
B737-400 & 0.00 & 0.05 & 0.05 \\
B747-400 & 0.01 & 0.06 & 0.07 \\
B757 & 0.01 & 0.05 & 0.06 \\
B767-300 & 0.01 & 0.05 & 0.06 \\
B777 & 0.00 & 0.06 & 0.06 \\
F100 & 0.00 & 0.05 & 0.05 \\
MD82 & 0.01 & 0.05 & 0.06 \\
Average & 0.01 & 0.05 & 0.06 \\
\hline
\end{tabular}

Source: Pearce and Pearce (2002).

To calculate the equivalent ad valorem ticket tax, note that fuel costs are currently close to 25 percent of airline revenues. ${ }^{57}$ A 10 percent tax on aviation fuel would thus be roughly equivalent to a 2.5 percent ticket tax. This would add roughly US $\$ 6$ to an average airfare ${ }^{58}$ (about US\$25 for business/first-class tickets, and US\$3 for economy tickets). With about 1.7 billion passengers expected to be carried in 2005 (about 1.5 billion in economy class, the rest in business and first class), the same tax revenue would be collected through a US\$5 departure tax on economy-class passengers, and a US\$15 departure tax on business- and first-class passengers.

\footnotetext{
${ }^{57}$ In 2003 , overall airline revenues were approximately US $\$ 400$ billion, and aviation fuel expenses approximately US\$50 billion (IATA, 2004 ), with a share of fuel prices in revenues of about 12 percent. This share has, however, risen rapidly over the last two years. In 2005, overall fuel expenses by airlines are likely to be in the range US\$80-100 billion, and the share of fuel expenses in revenue closer to 20 percent (Economist, November 12, 2005).

${ }^{58}$ This may be compared, for example, to the current U.S. homeland security charge of 7.5 percent.
} 


\section{B. Revenue}

Suppose first that there is no behavioral response to aviation taxation. Then a 20 cent fuel tax would raise on the order of US $\$ 10$ billion per annum. ${ }^{59}$ Applied only to international aviation - which accounted for about two-thirds of aviation fuel use in $2003^{60}$ — it would raise about US\$6.5 billion. Applied only in Europe (encompassing the EU and current non-EU members in Western and Eastern Europe including Russia, and covering both domestic and international flights), which accounts for nearly 30 percent of all passenger kilometers traveled by air, it would raise about US $\$ 3$ billion. The revenue patterns under a ticket tax of about 2.5 percent would be the same.

By way of comparison, a uniform departure tax raising US\$10 billion would require a charge of US\$6 if applied worldwide. Note also that a uniform departure tax levied in Europe alone would, in order to raise US\$10 billion, need to be set at US\$20, or about 16 euros.

Behavioral responses will tend, in somewhat different ways, to affect the yield of these taxes.

Taking first the ticket tax, demand will tend to fall in response to the increase in final price. Suppose for example a general price elasticity of demand of $-2 / 3$ (a level close to the average of the estimates reported above). The revenue impact of the consequent reduction in demand is modest: the revenue from a global tax falls from about US\$10 billion to around US $\$ 9.87$ billion, and from a tax in Europe alone from US\$3 billion to about US\$ 2.96 billion. ${ }^{61}$

For the aviation fuel tax, behavioral responses enter at two stages. First, airlines seek to mitigate the impact of the tax by increasing fuel efficiency. In the short run, they will try to counter fuel costs by utilizing energy-efficient planes more intensively and by increasing average airplane load factors (by systematically reducing seat vacancies and closing down routes with the lowest average seat capacity utilization). Some indication of the possible extent of such short-run improvements in fuel efficiency is provided by the response to the 2002-03 aviation fuel price hike (16 percent), which resulted in a 3 percentage point increase

\footnotetext{
${ }^{59}$ This is based on total civil aviation fuel use in 2003-for both domestic and international flights, and for both passenger and freight traffic (the latter accounting for about 12 percent of overall aviation fuel use) - of approximately 51 billion gallons (IATA, 2004).

${ }^{60}$ This is the proportionate usage for airlines that reported the breakdown to IATA (IATA, 2004).

${ }^{61}$ This uses the approximation that the revenue from the ticket tax is roughly $\tau Q X(1+\tau \varepsilon)$, where $\mathrm{Q}$ and $\mathrm{X}$ are pretax values.
} 
in average airline fuel efficiency worldwide. ${ }^{62}$ In the long run, further opportunities for improved fuel efficiency may arise, with a more rapid phasing out of less energy-efficient planes. ${ }^{63}$ This suggests that the 10 percent impact increase in fuel costs implied by the Pigovian tax would lead to a greater long-run increase in fuel efficiency, possibly as much as 3.5 percent. The second effect arises as final demand responds to increased ticket prices as a result of the (mitigated) increase in fuel costs, which (under the examples given above) is on the order of 1.5 percent. Combining these effects, the revenue from the global tax is reduced from US\$10 billion to US\$9.5 billion, and, for Europe alone, from US\$3 billion to US\$2.85 billion. ${ }^{64}$ As discussed above, revenue is thus somewhat lower under the fuel tax than under the ticket tax, reflecting the "distortion" of production decisions in the direction of less aviation fuel use - albeit a beneficial one, given the environmental damage — under the former but not the latter.

\section{Incidence}

Who would ultimately bear the burden of aviation taxes depends on details of market structure and adjustment. In the absence of a close analysis, the natural stylized assumptions appear to be that competition is sufficiently intense and returns to scale close enough to constant, to imply a very elastic supply of aviation services. Assuming too that oil supply, while relatively fixed in the short run, is highly variable over the longer term, a tax on aviation fuel will most likely be almost fully passed on into the input prices faced by airlines, and as a consequence, any increase in ticket prices will be fully borne by travelers. These, indeed, are the assumptions that implicitly underlie the analysis in Section $\mathrm{V}$ and the revenue estimates above.

A second dimension is the distribution of aviation taxes by travel class. Incidence by class will, for ticket taxes, depend on airline revenues from travelers in different classes, together with class-specific tax rates; for departure taxes it will depend on class-related traffic volumes and tax rates. With fuel taxes this is a more problematic issue as most flights have relatively fixed ratios between economy- and premium-class seats, while fuel can best be considered a fixed cost for each entire flight; the ascribing of fuel cost shares to different travel classes is in consequence somewhat arbitrary. In practice, it could plausibly be that airlines will tend to recuperate their increased fuel costs from different passenger segments according to the segment-specific demand elasticities.

\footnotetext{
${ }^{62}$ Average plane capacity utilization changed only marginally between 2002 and 2003 (IATA, 2004).

${ }^{63}$ Sledsens (1998) discusses technical possibilities for more efficient airplane design and how such designs can more quickly be phased in when fuel prices increase.

64 This uses the approximation that the revenue from the fuel tax is roughly $\tau X F\left(1+t\left(F^{\prime} / F\right)+(t F / Q) \varepsilon\right)$.
} 
Tables 8 and 9 give some information on such issues. Table 8 provides worldwide data on relative traffic volumes, in terms of numbers of passengers and passenger kilometers traveled, and on shares of airlines' revenues, all split up by economy, business, and first class. The table indicates that about 90 percent of all aviation travel (either in number of passengers or in traveled distance) is made up by economy-class travelers; about 9 percent by business-class travelers; and only about one percent by first-class travelers. For airline revenues, the shares for business and first class are higher and approach 30 percent in aggregate. ${ }^{65}$ Thus, a uniform departure tax (or alternatively, a fuel tax that is charged equally by distance to all travelers) would fall for 90 percent of its incidence on economy-class travelers, and for 10 percent on business- and first-class travelers. For a uniform ad valorem ticket tax, by contrast, almost 30 percent would fall on premium travelers.

Table 8. Overall Shares of Aviation Traffic by Travel Class, for Numbers of Passengers, Distance Traveled, and Airline Revenue

(Percentages of totals)

\begin{tabular}{lccc}
\hline Travel Class & $\begin{array}{c}\text { Share of Passenger Traffic, } \\
\text { Passenger Number }\end{array}$ & $\begin{array}{c}\text { Share of Passenger } \\
\text { Traffic, Traveled km }\end{array}$ & $\begin{array}{c}\text { Share of Airline } \\
\text { Revenue }\end{array}$ \\
\hline Economy class & 89.6 & 90.4 & 73.1 \\
Business class & 9.6 & 8.2 & 20.1 \\
First class & 0.8 & 1.4 & 6.7 \\
\hline
\end{tabular}

Source: Brian Pearce; IATA; and personal communication.

\footnotetext{
${ }^{65}$ It is perhaps surprising that the share of airline revenue from premium-class travelers is not even higher than this, given the figures in Table 6 for a (presumably representative) British Airways flight, which showed premium passengers representing roughly 50 percent of revenue. Possible explanations include: the figures in Table 8 are for aggregate world travel, while some airlines (such as British Airways) have more revenue from premium passengers than others; the premium passenger share of revenue is generally higher in international than in domestic travel; some (full-price) economy-class segments pay airfares close to those of business-class passengers; and that there has recently been some competitive pressure downwards on business-class ticket fares (Brian Pearce, IATA, personal communication).
} 
Table 9. Shares of Total Numbers of Air Passengers by Class, for Traffic Originating in Different Major Regions

(Percentages of total traffic)

\begin{tabular}{|c|c|c|c|c|c|}
\hline Data type & $\begin{array}{c}\text { Traffic } \\
\text { Originating } \\
\text { in Europe }\end{array}$ & $\begin{array}{c}\text { Traffic } \\
\text { Originating } \\
\text { in North } \\
\text { America }\end{array}$ & $\begin{array}{c}\text { Traffic } \\
\text { Originating } \\
\text { in Latin } \\
\text { America }\end{array}$ & $\begin{array}{c}\text { Traffic } \\
\text { Originating } \\
\text { in Asia and } \\
\text { Pacific }\end{array}$ & $\begin{array}{c}\text { Total Traffic } \\
1 /\end{array}$ \\
\hline Economy class & 85.0 & 89.0 & 91.1 & 90.5 & 89.6 \\
\hline Business class & 14.6 & 9.3 & 7.3 & 8.7 & 9.6 \\
\hline First class & 0.4 & 1.7 & 1.6 & 0.8 & 0.8 \\
\hline $\begin{array}{l}\text { Region's overall share of traffic, } \\
\text { Traveled kilometers }\end{array}$ & 28.4 & 35.5 & 5.0 & 23.9 & 100 \\
\hline
\end{tabular}

Sources: IATA (2004); Brian Pearce; and personal communication.

1/ Shares for regional traffic for regions specified do not add up to 100 percent, as not all regions are specified in the table.

Another dimension of incidence of interest — both in describing the potential impact of the tax and in suggesting likely sources of opposition - is that by region. This in turn has several aspects. The impact on any country's welfare is likely to depend, for example, on the direct impact on its own residents (by whichever carrier they travel), on the impact on its national carriers (whatever the residence of their passengers), or, for tourist destinations, on the volume of all leisure traffic. And the pattern of regional effects will also potentially differ by type of tax. Available data are such, however, as to enable only a few rather broad statements: ${ }^{.6}$

- $\quad$ Allocating the impact of a global aviation fuel tax in proportion to passenger kilometers flown ${ }^{67}$ (given that airline capacity utilization differs little between

\footnotetext{
${ }^{66}$ Domestic flights carried about twice as many passengers as international, but the latter are on average about three times longer; thus almost 60 percent of total passenger kilometers are flown internationally.

${ }^{67}$ The calculations below use data from IATA (2004). The passenger kilometers data reported here are found as the product of "available seat-kilometers" and the passenger load factor. (In 2003, the latter was about 71 percent. It has been relatively stable in later years, but increased by 1.2 percentage points from 2002-03, presumably in response to the general increase in fuel prices). When ascribing shares to countries and regions, half of each trip is ascribed to each end.
} 
regions), ${ }^{68}$ about 36 percent of the tax burden would fall on airplanes serving North America, about 28 percent on Europe, about 24 percent on East Asia and the Pacific, and about 12 percent on the other regions (South and Central America, Africa, the Middle East and South and Central Asia). These figures are also stated in the last line of Table 9 above.

- $\quad$ There appear to be no publicly available data on airline revenues by region that would enable a similar allocation of ticket taxes. To the extent that ticket prices per kilometer flown are typically lower for long-haul than for short-haul flights, the burden would tend to be tilted, compared to fuel taxes, to regions (such as Europe) in which international flights tend to be relatively short and fares consequently relatively high. ${ }^{69}$ It would also tend to fall more heavily, compared to a fuel tax, on premium-class use. This in turn increases the average burden on European compared to other travelers, due to the larger fraction of business-class travelers among this group (see Table 9).

- $\quad$ For departure taxes, the allocation would be proportional to the number of departing passengers from each country. In this case, since flights generated by the North American market are on the average longer than those generated by other markets, the shares of a common global tax allocated to Europe and to the Asia-Pacific regions would be somewhat greater, at about 31 and 26 percent respectively, and that allocated to North America lower, about 29 percent.

- Concern about the potential harm to the tourism sectors on which many low-income countries are heavily dependent prompts the thought of exempting all flights connecting to low-income countries from paying aviation taxes. Exempting all of Latin America and the Caribbean, Africa, and Asia (except Japan and other high-income countries) would eliminate approximately 25 percent of the global tax base (somewhat less in the case of ticket taxes, and somewhat more in the case of fuel taxes). Alternatively, only economy-class travel within and from such destinations could be exempted, in which case the tax base reduction would be on the order of 15 percent. While such exemptions may have some appeal from a distributional

\footnotetext{
${ }^{68}$ IATA (2004) data indicate that the three main regions, North America, Europe, and the Far East, have very similar fuel efficiency rates per passenger kilometer, so that passenger kilometer counts are reasonably good proxies for regional aviation fuel use. (Fuel efficiency is slightly lower in North America and slightly higher in the Far East, compared to Europe, mainly reflecting lower average age of aircraft fleets in the Far East).

${ }^{69}$ Kesharwani (2001) notes that in 2000 the worldwide average fare per passenger-kilometer for a distance of 16,000 kilometers was only 20 percent of that for a distance of 250 kilometers, and that average fares in Europe are three times as high as average fares in Asia and the Pacific for flights of 250 kilometers (almost all of which are domestic). Short flights are more fuel consuming per kilometer, but the difference is smaller and due to the greater fuel consumption in the take-off and ascent stage. Thus there would be a tendency for ticket taxes to fall to a larger extent on short trips, as compared to fuel taxes.
} 
perspective, they are clearly unwarranted from an environmental perspective, and will require higher overall tax rates in order to raise a given revenue target.

Table 9 shows the distribution of air travelers by class for flights originating in different major regions. In three of the regions (North America, Latin America, and Asia and the Pacific), distributions are similar, while the fourth, Europe, has a higher fraction of business-class travelers and lower in the two other classes. This serves to stress that a ticket tax levied proportionately on all ticket values would tend to fall relatively more on European than on other travelers. This effect would of course be strengthened by a higher rate of tax on premium-class travelers.

It may also be of some interest to consider the regional distribution of revenues from departure taxes (which may be differentiated by destination and travel class). Most likely the distribution will be quite similar to that of ticket taxes, but possibly tilted even more in the direction of regions (such a Europe) with short average trips.

One aspect of cross-country incidence that has aroused particular opposition to aviation taxes is the potential impact on tourist destinations (with the further twist that these are lower-income countries meant to benefit from development-oriented use of the proceeds). While this impact is likely to be highly country-specific, two general points are worth noting. First, the impact on any tourist destination of an increase in the price of traveling is likely to be lower the more tourist countries are affected by the scheme, since the demand faced by any is likely to be less responsive to the price increase if similar increases apply to its competitor countries. Second, since the relative increase in price-whether from a fuel tax, ticket tax, or departure tax - is likely to be lower for longer-haul flights, locations most distant from tourist origins ${ }^{70}$ — which may tend to be the lower-income amongst them - are likely to be less affected.

\section{Administration ANd COMPLIANCE}

There is in principle little technical difficulty in collecting taxes on aviation fuel, on tickets, and/or on departures.

Well-developed procedures for imposing excises on fuels are already in place in almost all countries, with the relatively small number of companies involved in importing and/or

\footnotetext{
${ }^{70}$ Recall that both fuel use and ticket price per kilometer traveled tend to decrease with distance.
} 
refining greatly facilitating control. ${ }^{71}$ Indeed, levying tax on fuel used in international aviation might well facilitate administration, since by narrowing the tax differential between fuels used internationally and domestically it would reduce the need to identify the use to which fuel is put. Ticket taxes are already in place in many countries, showing their feasibility. In this case, a key concern is to ensure that the tax is levied on final sales to the consumer, not, for instance, on sales from airlines to agents, since in the latter case scope would arise for transfer-pricing schemes intended to create artificially low prices at the stage at which the tax is levied. Departure taxes, of course, are already commonplace.

More difficult than the technicalities of tax collection is ensuring appropriate incentives for their collection if - as in recent proposals by proponents of aviation taxes to use the revenue raised to support development - proceeds do not accrue to the country that collects them. For it is a reasonable assumption that, for political reasons if no other, collection would be entrusted to participating countries rather than vested in a new supranational tax administration. But then incentives to devote scarce resources to the collection of these taxes, rather than to others that do benefit the national treasury, are clearly blunted. This effect can be mitigated by allowing the collecting authorities to retain some proportion of the receipts, perhaps on the order of 10 percent (which is the amount, for example, that EU member states retain of the customs duties they collect, which are then passed on to the EU budget). So long as the marginal retention rate is less than 100 percent, however, some reduction of collection incentives will always remain.

Moreover, and reinforcing this effect, the same considerations of national self-interest that lead countries to set inefficiently low levels of taxation in the absence of coordination, and so provide a rationale for that coordination, give them a further reason to enforce these taxes less intensively than they otherwise would. Countries that fear disadvantaging national carriers may be inclined to seek lengthier payment periods, for example, or to infrequently inflation-adjust taxes levied in specific form.

To participate in such schemes, countries will wish to be assured that other participants will comply with the rules of the commonly agreed tax schemes. This has two implications. The first is that agreement may need to be reached on quite detailed aspects of design and implementation, concerning not only the rate of the tax but also its precise base, the definition of those taxpayers that will be subject to it, and rules on such matters as payment periods, interest, and penalties. Second, countries may wish to have some direct means of verifying implementation by others. This might take a number of forms, such as participation

\footnotetext{
${ }^{71}$ The close monitoring to which international commercial air traffic is subject might also be used to support implementation, providing some potential check of fuel usage.
} 
in joint audit activities or the monitoring of aviation activity so as to derive independent estimates of the tax due. The pressures for some such mutual oversight are likely to be greater the larger the set of participating countries, both because weaker relations of bilateral trust may be involved and, more mechanically, because the consequences of game-playing by one will be spread across more countries, and hence will be less perceptible to each.

\section{Conclusions}

On pure tax policy grounds, the case for a generalized increase in taxes on international aviation is strong. Rates of tax are low at present, whereas there is quite persuasive evidence of significant cross-border damage from international air travel and, moreover, international air travel is in principle just as proper an object of indirect taxation as any other commodity. In terms of implementation and compliance too, these taxes are closely similar to ones that tax administrations and taxpayers are already well accustomed to. And while a further set of practical issues would arise if the revenue were devoted to other than national purposes, these are in qualitative terms no different from those that other candidate global taxes would raise (and in some respects may be eased by the existing close monitoring of aviation activity). In principle, and reflecting the two sets of policy concerns just mentioned, optimal aviation taxation is likely to involve a combination of both an excise on the use of aviation fuel (addressing the principal and most clearly established source of cross-border environmental harm associated with aviation), and a tax on tickets (focused on the objective of raising revenue), with the latter best taking the form of a VAT (so as to exclude business use, including through cargo). ${ }^{72}$

Indirect taxes on international aviation also have some particular appeal as a prospective source of development financing (leaving aside the additionality and other issues that apply to all such tax sources). Most of the activity is international, and thus does not naturally belong to any one nation, making it a natural target for international taxation: in a broad sense, the tax is a charge on use of a common resource. Another advantage, when looking into the future, is the likely buoyancy of tax base is very stable, with projections for high and stable future growth in international airline traffic (generally exceeding that for economic activity as a whole, and in spite of any possible dampening effect on activity that these taxes may have).

The main legal obstacles to a fuel tax of this kind are from mutual exemptions given under bilateral air service agreements - the Chicago Convention does not prevent countries from taxing aviation fuel for international use bunkered in their own borders - and even these, it

\footnotetext{
${ }^{72}$ Business travel of course would, and should, be affected by the fuel excise.
} 
appears, can in principle be overcome within the EU. ${ }^{73}$ It is reasonable to ask whether such restrictions, which appear to have originated at a time when the encouragement of the nascent international aviation travel industry was an object of policy, have outlived their usefulness. If taxes on international aviation fuels still cannot be levied, the case for ticket taxes becomes stronger; and in this case, in order to ensure that environmental costs are reflected in all travel decisions, including those of business travelers (and cargo), it should be in the form of a non-creditable excise rather than — or in addition to - a VAT of the kind that, as noted above, is best suited to raising revenue.

Even if legal impediments were removed, however, prospective tax competition between countries concerned to protect their national carriers, tourist industries, and revenues would likely mean that, in the absence of cooperation between them, the tax rates may tend to be set inefficiently low. Some degree of coordination in tax design and setting would be required, but since the tax base is less than perfectly mobile (flights between the United Kingdom and Norway are unlikely to be bunkered in the Pacific, for example), such taxes can clearly have effect even if levied on a regional rather than a universal basis.

The prospective revenue from optimal aviation taxes is significant. The estimate here is that fuel taxes set at a level that seems to roughly reflect associated environmental damageabout US\$0.20 per gallon, or 2.5 percent as a ticket tax (though this figure is subject to considerable uncertainty) — would raise a little under US $\$ 10$ billion if levied worldwide and a little under US\$3 billion if levied in Europe alone. To the extent that the presumed tax rate behind this calculation reflects only environmental concerns, not the desire for revenue as such, this is likely to be an underestimate of the revenue gain from collectively efficient aviation taxes.

Many countries, including both large, high-income countries with substantial shares of the market and smaller, low-income countries heavily reliant on tourism, are strongly opposed to any tax on international aviation. Clearly, too, in the present circumstances of high and uncertain future fuel prices, and with many airlines financially pressed, now is not the most propitious moment for increasing the burden on international aviation. ${ }^{74}$ And political

\footnotetext{
${ }^{73}$ See, for instance, the legal opinion on deployment of aviation fuel taxes in Germany (Pache, 2005).

${ }^{74}$ It is however not the case that the situation for the airline sector as a whole is currently bleak. In spite of increased fuel costs that have added at least US $\$ 40$ billion to airlines' gross expenses in 2005 over the previous year, most airlines outside of the United States are still running a surplus and are expecting strong demand increases (and several of the U. S. airlines are running "as normal" under Chapter 13 bankruptcy protection presumably in anticipation of better times). Economist (2005) reports that international demand for new aircraft has never been stronger. This is partly due to current demand for more fuel-efficient planes, but also to general demand for airline expansion, in particular for international travel.
} 
resistance to additional taxes on air travel remains strong in many countries. Nevertheless, France and Chile have recently committed to introducing new aviation departure taxes as a source of development finance. And such taxes are clearly feasible on a regional basis. The case for strengthening indirect taxation of intention aviation seems strong enough to warrant continued attention and closer analysis. 


\section{References}

Acemoglu, Daron and Asuman E. Ozdaglar, 2005, "Competition and Efficiency in Congested Markets,” Working Paper (Cambridge, Massachusetts: Massachusetts Institute of Technology).

Ashford, Norman and Clifton A. Moore, 1992, Airport Finance (New York: Van Nostrand Reinhold).

Atkinson, Anthony B., 2005, New Sources of Development Finance (Oxford: Oxford University Press).

Baily, Martin Neil, Robert J. Gordon, and Timothy F. Bresnahan, 1993, "Competition, Regulation, and Efficiency in Service Industries," Brookings Papers on Economic Activity 2, 71-159.

Baumol, William, John Panzar, and Robert Willig, 1982, Contestable Markets and the Theory of Industry Structure (San Diego: Harcourt Brace Jovanovic).

Betancor, Ofelia, and Gustavo Nombela, 2002, Mohring Effects for Air Transport, "UNITE Competitive and Sustainable Growth Programme," Workpackage 7: Case Study 7 (Las Palmas, Spain: EIET University of Las Palmas).

Bleijenberg, A., and R. Wit, 1998, "European Environmental Aviation Charge-Feasibility Study," (unpublished; Delft: Centre for Energy Conservation and Environmental Technology).

Boadway, Robin, and Michael Keen, 2005, "Notes on the Provision of International Public Goods" (unpublished; Washington: International Monetary Fund).

Borenstein, Severin, 1989, "Hubs and High Fares: Dominance and Market Power in the U.S. Airline Industry,” Rand Journal of Economics, Vol. 20, pp. 344-65.

, 1991, "The Dominant-Firm Advantage in Multiproduct Industries: Evidence from the U.S. Airlines," Quarterly Journal of Economics, Vol. 106, pp.1237-66.

, 1992, "The Evolution of U.S. Airline Competition," Journal of Economic Perspectives, Vol. 6, pp. 45-73.

, and Nancy L. Rose, 1994, "Competition and Price Dispersion in the U.S. Airline Industry," Journal of Political Economy, Vol. 102, pp. 653-83. 
Bovenberg, A. Lans and Lawrence H. Goulder, 1996, "Optimal Environmental Taxation in the Presence of Other Taxes: General Equilibrium Analyses," American Economic Review, Vol. 86, pp. 985-1000.

Brueckner, Jan K., 2002, “Airport Congestion When Carriers Have Market Power,” American Economic Review, Vol. 92, pp. 1357-75.

Delipalla, Sofia, and Michael Keen, 1992, “The Comparison Between Ad Valorem and Specific Taxation Under Imperfect Competition," Journal of Public Economics, Vol. 49, 351-67.

,2005, "Product Quality and the Optimal Tax Structure," Journal of Public Economic Theory, forthcoming.

Diamond, Peter A., and James A. Mirrlees, 1971a, "Optimal Taxation and Public Production I: Production Efficiency," American Economic Review, Vol. 61, pp. 8-27.

, 1971b, “Optimal Taxation and Public Production II: Tax Rules," American Economic Review, Vol., 61, pp. 261-78.

Dixit, Avinash K. and Joseph E. Stiglitz, 1977, "Monopolistic Competition and Optimum Product Diversity,” American Economic Review, Vol. 67, pp. 297-308.

Doganis, Rigas, 2001, The Airline Business in the $21^{\text {st }}$ Century (London and New York: Routledge).

ECON, 2005, "Political Economy of the Norwegian Aviation Fuel Tax," ECON Report 2005-017 (Oslo: ECON Analysis).

Economist (2005), “Lining Up for Profits,” November 12, pp. 71-73.

Edmondson, Duncan, Richard Hancox, Steve Lowe, and Hans Pulles, 2005, "Quantifying the Environmental and Economic Impacts of Market-Based Instruments to Reduce Aircraft Emissions," Report written for the Civil Aviation Department (the Hague).

European Commission, 1999, Resource Analysis (Brussels).

, 2005a, "A Possible Contribution Based on Airline Tickets as a New Source of Financing Development: Technical Reflections in the Run up to the UN High Level Event," European Commission Staff Working Paper 1067 (Brussels). 
, 2005b, "New Sources of Financing for Development: A Review of the Options," European Commission Staff Working Paper 467 (Brussels).

Evans, William N., and Ioannis Kessides, 1993, "Localized Market Power in the U.S. Airline Industry," Review of Economics and Statistics, Vol. 75, pp. 66-75.

Evers, Michiel, de Mooij, Ruud, and Vollebeergh, Herman R. J. 2004, "Tax Competition under Minimum Rates: The Case of European Diesel Excises," CESifo Working Paper No. 1221.

Friedrich, Rainer, and Peter Bickel, eds., 2001, Environmental External Costs of Transport (Berlin: Springer Verlag).

Gillen, David W., William G. Morrison, and Christopher Stewart, 2004, “Air Travel Demand Elasticities: Concepts, Issues and Measurement," Report written for Department of Finance, Canada (Ottawa).

Goolsbee, Austan, and Chad Syverson, 2005, "How do Incumbents Respond to the Threat of Entry? Evidence from Major Airlines,” NBER Working Paper 11072 (Cambridge, Massachusetts: National Bureau of Economic Research).

Hanlon, Pat, 1999, Global Airlines. Oxford: Butterworth Heinemann.

Hendricks, Kenneth, Michele Piccione, and Guofu Tan, 1997, "Entry and Exit in Hub-Spoke Networks," Rand Journal of Economics, Vol. 28, pp. 291-303.

Hurdle, Gloria J., Richard L. Johnson, Andrew S. Joskow, Gregory J. Werden, and Michael A. Williams, 1989, "Concentration, Potential Entry, and Performance in the Airline Industry," Journal of Industrial Economics, Vol., 38, pp. 119-39.

IATA, 2004, World Air Transport Statistics, (Montreal and Geneva: International Air Transport Association). , 2005a, IATA List of Ticket and Airport Taxes and Fees (Montreal and Geneva: International Air Transport Association).

,2005b, "Aviation Taxes and Charges: A Comparison of the Level of the Taxation, Subsidies and Charges for Aviation and for Other Transport Modes in Germany, France and the United Kingdom," unpublished report, November (Montreal and Geneva: International Air Transport Association). 
ICAO, 1985 “Manual on Air Traffic Forecasting,” ICAO Document 8991-HT/772/2 (Montreal: International Civil Aviation Organization). , 2000, "ICAO's Policies on Taxation in the Field of International Air Transport," ICAO Document 8632 (Montreal: International Civil Aviation Organization). , 2001, “Airports and Route Facilities, Financial Data and Summary Statistics," ICAO Digest of Statistics, No. 509 (Montreal: International Civil Aviation Organization).

IPCC, 1999, Aviation and the Global Atmosphere (Montreal: Intergovernmental Panel on Climate Change).

Kanbur, Ravi and Michael Keen, 1993, "Jeux Sans Frontières: Tax Competition and Tax Coordination When Countries Differ in Size," American Economic Review, Vol., 83, pp. 877-92.

Katz, Michael L. and Karl Shapiro, 1994, "System Competition and Network Effects," Journal of Economic Perspectives, Vol. 8, pp. 93-115.

Keen, Michael, 1998, “The Balance Between Specific and Ad Valorem Taxation," Fiscal Studies, Vol. 19, pp. 1-37. , and Jon Strand, 2005, "Optimal Aviation Ticket and Fuel Taxes with Factor Substitution," Note, Fiscal Affairs Department (Washington: International Monetary Fund).

Kesharwani, Tulsi, 2001, "Pricing and Charges in Civil Aviation," Economic Issues 5, (New Delhi: Asian Institute of Transport Development).

Kolstad, Charles D., 2000, Environmental Economics (New York: Oxford University Press).

Konrad, Kai and Guttorm Schjelderup, 1998, "Fortress Building in Global Tax Competition," Journal of Urban Economics Vol. 46, pp. 156-67.

Laffont, Jean-Jacques, Patric Rey, and Jean Tirole, 1998a, "Network Competition: I, Overview and Nondiscriminatory Pricing," Rand Journal of Economics, Vol., 29, pp. 1-37. , 1998b, "Network Competition: II, Price Discrimination," Rand Journal of Economics, Vol. 29, pp. 38-56. 
Landau, Jean-Pierre, and others, 2004, Landau Report, by a Multi-Disciplinary Working Group set up by the French Government (draft; Paris).

Mayer, Chris and Todd Sinai, 2003, "Network Effects, Congestion Externalities, and Air Traffic Delays: Or Why Not All Delays are Evil," American Economic Review, Vol. 93, pp. 1194-1215.

Mohring, H., 1972, "Optimization and Scale Economies in Urban Bus Transportation," American Economic Review, Vol. 62, pp. 591-604.

Morrison, Steven A., 2001, “Actual, Adjacent, and Potential Competition: Estimating the Full Effect of Southwest Airlines," Journal of Transport Economics and Policy, Vol. 32, pp. 239-256.

NBAA, 2005, Federal Excise Tax Handbook (Washington: National Business Aviation Association).

Oum, T. H., A. Zhang, and Y. Zhang, 1995, “Airline Network Rivalry,” Canadian Journal of Economics, Vol. 4a, pp. 836-57.

Pache, Eckhard, 2005, “Options of Introducing a Tax on Kerosene Consumed on Domestic Flights - Legal Opinion by Order of the Federal Environmental Agency, Note” (Würtzburg, Germany).

Parry, Ian W.H., 1995, "Pollution Taxes and Revenue Recycling," Journal of Environmental Economics and Management, Vol. 29, pp. S64-S77.

, 2002, “Is Gasoline Undertaxed in the United States?” Resources, Vol. 148, pp. 28-33. , and Antonio M. Bento, 2001, "Revenue Recycling and the Welfare Effects of Road Pricing," Scandinavian Journal of Economics, Vol. 85, pp. 333-62.

, and Kenneth A. Small, 2005, "Does Britain or the United States have the Right Gasoline Tax?" American Economic Review, pp. 1276-89.

Pearce, Brian D. and David W. Pearce, 2002, "Setting Environmental Taxes for Aircraft: A Case Study of the U.K.," Working Paper (London: Forum for the Future/University College).

Pirttilä, Jukka, 2002, "Specific Versus Ad Valorem Taxation and Externalities," Journal of Economics, Vol. 76, pp. 177-87. 
Quadripartite Report, 2004, Report of the Technical Group on Innovative Financing Mechanisms (Geneva: United Nations).

Reiss, Peter C. and Pablo T. Spiller, 1989, "Competition and Entry in Small Airline Markets,” Journal of Law an Economics, Vol. 32, pp. S179-S202.

Sandmo, Agnar, 1975, “Optimal Taxation in the Presence of Externalities." Swedish Journal of Economics, Vol. 77, pp. 86-98.

, 2003, "Environmental Taxation and Revenue for Development," Working Paper (Bergen: Norwegian School of Economics and Business Administration).

Selrod, Rolf, 1995, "A Painless Solution? An Analysis of Two Alternatives for Global Taxation for Financing Climate Activities under the United Nations Umbrella," CICERO report 1995:07 (Oslo: CICERO).

Singh, Damanjit, 2004, “Charging Traffic Congestion: A Potential Source of Municipal Revenue?" (unpublished; Washington: International Monetary Fund).

Sledsens, T., 1998, Sustainable Aviation: The Need for an European Environmental Aviation Charge (Brussels: European Federation for Transport and Environment).

Strand, Jon, 2005a, "Optimal Aviation Taxes with Distortive Taxation and Endogenous Labor Supply” (unpublished; Washington: International Monetary Fund).

, 2005b, “Optimal Aviation Taxes with Non-Competitive Airlines" (unpublished; Washington: International Monetary Fund).

Strassman, Diana L., 1990, "Potential Competition in the Deregulated Airlines," Review of Economics and Statistics, Vol. 72, pp. 696-702.

Transportation Research Board, 1999, Entry and Competition in the U.S. Airline Industry, Special Report No. 255 (Washington: Transportation Research Board).

WBGU, 2002, "German Advisory Council on Global Change, Charging the Use of the Global Commons" (Special Report; Berlin: German Advisory Council on Global Change).

Whinston, Michael D. and Susan C. Collins, 1992, "Entry and Competitive Structure in Deregulated Airline Markets: An Event Study Analysis of People Express," Rand Journal of Economics, Vol. 23, pp. 445-62. 
World Bank, 2005, “Aid Financing and Aid Effectiveness,” Board Note, SecM2005-0435 (Washington: World Bank).

Zee, Howell, 2005, “A Note on Global Taxes and Aid for Development” (unpublished; Washington: International Monetary Fund).

Zodrow, George and Peter Mieszkowsi, 1986, "Pigou, Tiebout and the Underprovision of Local Public Goods," Journal of Urban Economics, Vol. 19, pp. 356-70. 